\title{
Kapitalizm - Mekân İlişkisi: Fordist 'Sanayi/İşçi' Kenti İle Post-Fordist 'Küresel/Hizmet' Kenti Karşılaştırması Üzerinden Bir Değerlendirme
}

\author{
Capitalism-Space Relationship: An Evaluation of the Comparison of the \\ Fordist 'Industrial/Worker' City with the Post-Fordist 'Global/Service' City
}

\author{
Çiğdem Şahin ${ }^{1}$ (1)
}

Öz

Sermaye birikim sürecinde 'kent', hem üretim ilişkilerinin içinde gerçekleştiği yer olma özelliğine sahip olması bakımından hem de zamanla sermaye tarafindan metalaştıılarak kullanılan bir birikim kaynağına dönüşsmesi nedeniyle oldukça önemli bir işleve sahiptir. Kapitalizmin her safhasında gerek fiziki gerek sosyo-ekonomik koşullarıyla önemli ölçüde farklılaşan 'kent', her yeni dönemde işlevsel ve yapısal olarak farklı form ve rollerle karşımıza çıkmaktadır. Bu makalenin başlıca amacı öncelikle kapitalizm ve mekan ilişkisini sorgulamak ve sonra kapitalizmin farklı dönemlerinde kentte gerçekleşen değişim ve dönüşüm süreçleri ile kapitalist üretim ilişkilerinin bağlantısını kurmaktı. Bunu da özellikle iki farklı kapitalist dönemi baz alarak, Fordist ve Post Fordist safhada, bir dönemden diğer döneme geçişte değişen dinamikler üzerinden gerçekleştirmektir.

Anahtar Kelimeler

Fordizm, Kapitalizmin misafirhaneleri, Kürsel kent, Neo-liberalizm, Sanayi/Işçi kenti, Post-fordizm

\begin{abstract}
In the capital accumulation process, the 'city' has a rather important function both from the perspective that it is the place where production relations take place and as it has, in time, been transformed into a tool of accumulation, commodified and used by capital. The "City", which has changed significantly with both its physical and socio-economic conditions at every stage of capitalism, presents itself with different functional and structural forms and roles in every new phase. The main purpose of this article is to connect the processes of change and transformation that have taken place in the city in different periods of capitalism with the relations of capitalist production. It does this by focusing particularly on two different capitalist periods, the Fordist and Post-Fordist stages, and examining, in this context, the dynamics that emerged during the transition from one period to the next.
\end{abstract}

\section{Keywords}

Fordism, The guesthouses of Capitalism, Global city, Neo-liberalism, Industry / Workers city, Post-Fordism

1 Sorumlu Yazar: Çiğdem Şahin (Dr. Öğr. Üyesi), İstanbul Üniversitesi, İktisat Fakültesi, İktisat Bölümü, İstanbul, Türkiye. E-posta: csahin@istanbul.edu.tr ORCID: 0000-0002-5922-5875

Attf: Sahin, C. (2020). Kapitalizm-Mekân illişkisi: Fordist 'Sanayi/İşçi' Kenti i̇le Post-Fordist 'Küresel/ Hizmet'Kenti Karşılaştırması Üzerinden Bir Değerlendirme. Sosyal Siyaset Konferansları Dergisi, 79, $237-275$. https://doi.org/10.26650/jspc.2020.79.0048 


\section{Extended Summary}

Robert Park states that "People are reproducing themselves as they produce their city". It is possible to partly agree with this view. However, according to the opinion defended in this article, individuals are not completely free in the process of 'designing' and 'creating' the city. Capital's reproduction conditions determine the city, just as it determines the region and the place. In this respect, it is not possible to establish and construct a city independent of capitalist production relations. The 'City', as in utopian views, is not an independent, imaginary design produced by architects. At least, such freedom does not exist in the capitalist system. In the capitalist system, the same capitalist dynamics and capital accumulation laws are valid in the formation and transformation processes of the city as well as all other superstructure institutions and formations. Capital needs favorable geographical, physical conditions and places in order to reproduce itself. It can be a region or a city; what is important is that Capital has the power to change and transform every object, natural life, environment, geography and space in line with its needs in the process of reproducing itself. As well as having this power, it also has the power to change, transform and reconstruct 'Rural' and 'Urban' in the same way. Given this decisive feature of capitalism, which population will periodically concentrate in which region of the city in each capitalist phase; how to share urban areas between different classes and what kinds of 'Class' and 'Spatial' separations will be experienced as a result. It should not be considered independent of capitalist relations of production and sovereign power relations. In the sample analysis section of the article, two different Capitalist periods are discussed: the Fordist and Post Fordist Capitalist period. Two different 'City' structures emerging in these two periods are discussed and first of all, the connection of the two City formation processes with 'Capitalist production relations and capital accumulation conditions' is examined. Then it is concluded that the dynamics that transformed the Fordist Worker / Industrial city and the dynamics that transformed the Global / Service City of the Post-Fordist Neo liberal process are based on the same basis. That is, the dynamics that transform both cities are considered to be subject to the same unchanging capitalist capital accumulation laws and relations of production. As a result, 'Capitalist production relations' and 'Capital accumulation conditions' are the main determinants in the transformation and restructuring process of the city. This does not change even though there are two different forms and features of the City that have 
occurred in two different capitalist periods. The basic determinants and dynamics of the formation process and structuring of both cities are also subject to the same 'Capital accumulation law' and 'Capitalist production relations'. 


\section{Kapitalizm - Mekân İlişkisi: Fordist 'Sanayi/İşçi' Kenti İle Post-Fordist 'Küresel/Hizmet' Kenti Karşılaştırması Üzerinden Bir Değerlendirme}

Bilindiği gibi akademik çalışmalarda kuram, yöntem, teorik referanslar, iç ve dış dinamiklerin birlikte ele alınıp alınmadığı, eleştirel bir yaklaşımın olup olmadığı gibi etmenler çalışmanın bilimsel niteliğini ve güvenirliğini etkilemektedir. Konu, 'kapitalizm ve mekân' ilişkisi, daha dar kapsamda da 'kapitalizm ve kent' ilişkisi olduğunda, bu yöntem ve yaklaşım sorunu daha da önem kazanmaktadır. Özellikle alt-yapı ve üst-yapı ilişkisinde belirleyicilik yaklaşımının nasıl oluşturulduğu; kent veya mekanın tarihsel bir süreç içinde ortaya çıkan bir olgu olarak mı yoksa sadece kendi dönemine ait bağımsız bir yapı olarak mı ele alındığı; süreç boyunca süreklilik arz eden etmenlerle geçici, her safhada değişiklik gösteren dinamikler ayrımının yapılıp yapılmadığı; nihayetinde bütün bu olgu ve kavramların birbirleriyle nedensellik ilişkisinin kurulup kurulmadığı gibi faktörler araştırma bulgularını ve sonucu ciddi ölçüde değiştirebilmektedir. Örneğin, "kapitalizm mekân tamamıyla belirler mi yoksa kapitalizmden bağımsız bir 'mekân' tasarımı ya da 'kent' oluşumunun gerçekleşmesi mümkün müdür?” sorunsalını ele alırsak, yukarıda altı çizilen kriter ve kuramsal yaklaşım tercihinin nasıl yapıldığına göre çalışmanın çıkarımlarının ve verilerinin farklılaşacağı görülecektir. Makalede bu bağlamda öncelikle teorik yaklaşım ve yöntem ortaya konularak çalışmanın kuramsal çerçevesi çizilmektedir. Sonra 'kapitalizm ve mekân ilişkisi yukarıda da belirtilen kuramsal çerçevede, öncelikle kapitalizmden bağımsız bir mekan tasarımının veya üretiminin mümkün olup olmadığı sorusuna yanıt aranarak irdelenmektedir. Daha sonra da kentin kapitalist sistemde bir mekân olduğu varsayımı altında, 'sermaye birikim' sürecinde farklı kapitalist safhalarda farklı kent formlarının üretimi konusu açıklığa kavuşturularak kentin her dönem bu farklı form ve işlevle karşımıza çıkmasının üretim ilişkileri ve kapitalist sermaye birikim yasaları ile nedensellik bağları sorgulanmaktadır. Konunun somut örnek analizinde ise Fordizmin 'sanayi/işçi kenti' ile Post-Fordizmin soylulaştırılmış 'küresel kenti' temel nitelikleri ve dönüştürücü dinamikleriyle karşılaştırmalı olarak çözümlenmektedir. Her iki döneme ait kent yapılanmasının farklı özellikler taşımasına ve farklı karakterlerinin olmasına rağmen son kertede kentin bu dönemsel süreçlerini belirleyen asıl dinamiğin 'kapitalist üretim ilişkileri' ve ‘sermayenin kendini yeniden üretme koşulları' olduğu saptamasıyla çalışma son bulmaktadır. 


\section{Çalışmanın Teorik Çerçevesi ve Temel Referanslara Vurgu}

'Kapitalizm ve mekân' konusu Marksist yaklaşımlarca özellikle 1960'lardan sonra yoğun olarak tartışılmaya başlanan bir konu olmakla beraber, 'kent' teması çok eski yıllardan beri ele alınan ve bu konuda çok farklı ekoller bulunan bir meseledir. Bu yaklaşım zenginliği ve teorik tartışmaların çeşitliliğini gösterebilmek açısından konuyu araştıran Trut ve Özgür'ün çalışmsında ortaya konduğu üzere 'kent' konusunda klasik yaklaşımlardan radikal ve alternatif yaklaşımlara kadar bir çok ekol ve anlayış bulunmaktadır. Bunları başlıklar halinde belirtmek gerekirse çalışmada şöyle bir sınıflandırma yapılmaktadır:

1. Klasik Kent Kuramları/Kavramsallaştırmaları, 1.1. Ekonomi-Politik Yaklaşımı 1.2. Weber ve İdeal Kent 1.3. Simmel, Kent ve Yabancılaşma

2. Chicago Ekolü Kent Kuramları (Ekolojik Kent Kuramları) 2.1. R. Park ve Kentsel Ekoloji Kuram1 2.2. Burgess ve Tek Merkezli Daireler Kuram1 2.3. McKenzie ve Kentsel Ekolojik Büyüm 2.4. Wirth ve Yaşam Biçimi Olarak Kentlileşme 2.5. Harris ve Ullman'ın Kentin Doğası

3. Çağdaş (Radikal) Kent Kuramları 3.1. Lefebvre ve Toplumsal Ürün Olarak Mekân 3.2. Manuel Castells, Kolektif Tüketim ve Kentsel Hareketler 3.3. Harvey ve Sermaye Birikimi Olarak Kent 3.4. Brenner (ve Yeni Nesil Kent Teorisyenleri) ve Neo-liberalizmin Kentleşmesi (Trut ve Özgür, 2018).

Bu çalışmada genel olarak 'Ekonomi-politik yaklaşımı' ve daha dar çerçevede de yine Marksist ama çağdaş ekolü temsil eden 'Harvey'in Sermaye Birikimi' yaklaşımı referans alınmaktadır. Fazlasıyla çeşitlilik arz eden ve yer yer karmaşık hale de gelen diğer yaklaşımlara tek tek değinmek ve karşılaştırmalar yapmak çalışmayı ana ekseninden uzaklaştıracağ 1 için, makalede teorik yaklaşım olarak sadece Marksist çerçeve ayrıntılı olarak ele alınmış, 'kapitalizm ve mekân konusu bu temelde özellikle Harvey ve Sermaye Birikimi ekolü referans alınarak işlenmiştir. Yeri geldikçe, Marksist kuramcıların kendi aralarındaki nüansları ortaya koymak amacıyla Marksist ekolden diğer kuramcıların görüşlerine de yer verilmiştir. Marksizmin 'mekan ve kentler' konusundaki sessizliğini oldukça ironik bulan Ira Katznelson, 'Marxsizm ve Kent' kitabında, kentsel mekân konusu önemli mi, önemsiz mi ya da ne zaman önemli olduğu konusunda Marxizmin çok az şey söylediğini, Engels'in 1845 yılında ingiliz işçi sınıfının oluşumunun ilk dönemlerinde kentleri değerlendirdiği yayınından 100 yıl sonraya kadar bu konunun Marksist kuram içinde adeta 
görmezden gelindiğini belirtmektedir. Ona göre1960'lara kadar bunun tek önemli istisnası II. ve III. Enternasyonal'de yer alan sosyalizme geçerken kent ve kırsal arasındaki ilişki tartışmalarıdır (Katznelson, 2019: 47-48). Bununla birlikte Katznelson, Marx ve Engels'in kenti açıkça kuramsal olarak temel bir analiz nesnesi yapmış olmasa da, üretim biçimlerindeki dönüşümler hakkındaki değerlendirmelerinde, işbölümü sorunsalı içinde, kentleşme ve kent konularına oldukça fazla önem verdiğini, özellikle Marx'ın, Kapital'in ilk cildindeki 'İş ve İmalat Ayrımı' bölümünde kullandığı "her iyi geliştirilmiş ve mal mübadelesinden doğan işbölümünün temelinde kent ve kırsal ayrım yatar” ifadesinin buna somut bir örnek olduğunu belirtmektedir. Yine kendi dönemlerindeki diğer yaklaşımların aksine, Marx ve Engels’in, kentsel ve mekânsal güçlerin bağımsız bir duruşları olduğu konusunda da net olduğunu, bu konuda "kent ve kırsal arasındaki ayrımın, işbölümünün gerekliliklerinin üretim biçiminin seviyesinden anlaşılan, direkt ve araçsız bir sonucu olduğu” vurgularının olmasının bunu desteklediğine dikkat çekmektedir (Katznelson, 2019: 50). Sadece bir çeyrek yüzyıl önce hakim olan durumun tersine Marksist geleneğin içinde kent hakkında büyük bir çalışma dağarcığının oluştuğuna da vurgu yapan Katznelson, Marksizm içinde kentsel bir tartışmanın yeniden canlanmasında ise, 1960'ların sonu, 1970'lerin başında Henri Lefebvre'nin 'Marksist Düşünce ve Kent' (Lefebvre, 1968) adlı kitabı başta olmak üzere, Manuel Castells'in 1972' de yayınlanan 'Kent Sorunu' (Castells, 1972) ve David Harvey'nin 'Sosyal Adalet ve Şehir' adlı çalışmalarının çok etkili olduğunu belirtmektedir (Katznelson, 2019: 54, 55).

“Kapitalizm ve Kent: Bir Tarihselleştirme Denemesi” makalesinin giriş bölümünde "Kente dair girişilecek tüm tarih yazımı denemeleri, doğal olarak, bir tanımlama çabasını da beraberinde getirecektir. Bu tanım, tarih boyunca kente atfedilen işlevler tarafından belirlendiği için sürekli değiş̧mek durumundadır" ifadesini kullanan Güven ise açılamasında kentsel yerleşimlerin insanlık tarihi boyunca tanımlaması yapılırken, kente dair bu tanımlamaların aynı zamanda içinde yaşanılan dönemin ifadesi olarak da görülmesi gerektiğini; sadece dönemin kente atfettiği işlevlerle kenti açıklamanın mümkün ve uygun olmadığını, içinde bulunulan dönemin hakim yazını ya da insanlığın gelişim sürecine dair daha üst soyutlama düzeylerindeki bazı kavramlaştırmaların da içine alındığı bir kent tanımının yapılmasının daha doğru olacağını savunmaktadır (Güven, 2014: Giriş). Güven'in bu altını çizdiği ;“kentin içerdiği yoğunlaşma ve tarihsel olarak ileri atılımlara olanak sağlayan yapısından dolayı, kent 
çözümlemesini sınıf mücadelesi ile ilişkilendirilme" anlayışı ve yukarıdaki 'tarihsel süreç içinde olguların değerlendirilmesi' olarak sunulan Marksist perspektif, 1960 sonrası ‘kapitalizm ve mekân’ bağlamında gerçekleştirilen yeni Marksist kent çalışmalarının da belirgin özelliğini oluşturmaktadır. Güven bu anlayışın avantajlarını değerlendirirken, Lefebvre'in 'Babil Kulesi Karmaşıklığı' dediği durumu aşmanın bir aracı olarak, klasik felsefeden farklı bir praksis felsefesi olması ve dar bilimsel metodolojilerden ayrı bir bütünlük anlayışına sahip olması sayesinde Marksizmin kenti anlamak açısından çok önemli bir araç setine ve yönteme sahip olduğunu, bunu diğer tüm bilimleri ikame ederek yapmamakla birlikte avantajının diğer yaklaşımlar arasındaki eklemlenmeyi sağlayarak ve farklı soyutlama düzlemlerindeki bulguları birleştirerek bütünlük sağlamak olduğunu, bu bağlamda diyalektik yöntemin halen elimizdeki en gelişkin ve güçlü araç olarak kabul edilebileceğini ileri sürmektedir(Güven, 2014: Giriş).

Sınıf çatışmasına dayalı dinamik yaklaşımın kaynağına gidilirse, Marx ve Engels'in bu konuda özellikle Komünist Manifesto'da kullandığı şu ifadeleri oldukça önemlidir: "Üretimin sürekli devrimci dönüşümlere uğratılması, tüm toplumsal koşulların kesintisiz şekilde sarsılması, sonu gelmez belirsizlik ve hareket, burjuva çağını diğer tüm çağlardan ayırır. Tüm sabit, küflü ilişkiler, beraberindeki eskiden saygıdeğer bulunan düşünceler ve görüşlerle birlikte çözülüyor; yeni oluşmuş olan tüm ilişkiler daha kemikleşmeden eskiyor. Sabit ve durağan olan her şey buharlaşıyor, kutsal olan her şey ayaklar altına alınıyor ve insanlar sonunda yaşam koşullarına ve karşılıklı ilişkilerine ayık kafayla bakmak zorunda kalıyor"(Marx ve Engel, 2011: 14). Burada kapitalizmin yıkıcı etkisine olumlu bir vurgu yapan Marx ve Engels bir yandan da kapitalizmin asıl dinamiğinin çatışmalardan beslendiğine, özellikle de sınıf çatışmasının tüm tarihsel değişim ve dönüşümleri belirlediğine dikkat çekmektedir. Bunun bir örneği de Marksizmin bu konudaki "tüm toplumların tarihinin sınıf çatışmalarının tarihi olduğu” konusundaki öngörüsüdür. Güven'e göre 'çözülmek' ve 'yeniden kurulmak' zorunda kalan yapılardan birisi de kenttir ve 1850 'ler, burjuvazinin bunu keşfettiği yıllardır. Bu yıllar bir yanıyla yenilenme, yeni ilişki biçimleri kurma anlamına gelirken bir diğer yanıyla da belirsizlik, düzensizlik anlamına gelmektedir. Sermayenin çevrim hızının görece daha düşük olduğu 1850'lerde bu durum bir yenilenme olarak değerlendirilebilirken sermaye çevrim hızının daha çok arttığı dönemde ise düzensizlik olarak ortaya çıkmaktadır (Güven, 1914). 
Kapitalizmle kent arasında ilişkiyi, keskin bir dönemleştirmeden ziyade belli momentlere odaklanılarak incelenmek ve her biri belli özel dönemlere denk düşen momentlerin, kapitalizmin kentle nasıl bir ilişki kurduğunu ve bu ilişkinin nasıl dönüştügüünü anlamak açısından ele almak Güven'in de altını çizdiği şekilde 'kent' çalışmalarında önemli bir noktadır. Özellikle 'kapitalizm ve mekân' ilişkisi bağlamında 'kent ‘ üzerine yapılan birçok Marksist çalışmada, kapitalizmin kendisinden önceki üretim biçiminden kenti nasıl devraldığ 1 , bu kentin içine nasıl yerleştiği ve başat bir unsur haline dönüştüğü, ardından kapitalizmin devraldığı yapıyı nasıl dönüştürdüğü, kente yerleştikten ve ev sahibi olduktan sonra kapitalizmin dönemin ihtiyaçlarına göre aldığı konumlar, kentle girdiği ilişki biçimleri, temel olarak da 20. yy’ın ilk yarısı incelenerek kapitalizmin kendi yarattığı kent kurgusunun siyasal ve iktisadi gereklilikleriyle nasıl yeniden yapılandırıldığı şeklindeki bütünlüklü bir yaklaşım, esas olarak Marksizmin yapısalcı ve diyalektik anlayışının bir sonucu olarak görülm elidir.Bu makalede de kapitalizmin farklı dönemlerinde, üretim ilişkileri çerçevesinde ortaya çıkan farklı kent oluşumları ve dinamiklerine önem verilmekle beraber esas olarak kapitalizmin başlıca iki dönemine ait 'kent' olgusunun, Fordist dönemin sanayi kapitalizmine ait 'işçi kenti' ile günümüz küresel kapitalizmin asli unsuru olan 'küresel kent' olgusunun karşılaştırması yapılmaktadır. Esas olarak odaklanılan konu ise, Fordizmin ‘sanayi/işçi kenti’ ve neo-liberalizmin soylulaştırılmış 'küresel kenti' gibi iki çok farklı 'kent yapısının ortaya çıkma sürecinin ve bunu belirleyen temel dinamiklerin kapitalist üretim ilişkileri ve sermaye birikim koşulları ile bağlantısının kurulmasıdır. Özellikle 'sanayileşmiş, kamusal yarar odaklı planlamaya ağırlık verilmiş Fordizmin sanay/işçi kentinden, neo-liberalizmin küreselleşmiş, sınıfsal ve mekansal ayrışmalarla sanayiden ve yoksullardan arındırılmış 'soylulaşmış' küresel/hizmet kentine geçişin, 'Kapitalist Sermaye Birikim' koşulları açısından temel dinamiklerinin ele alınması ve Fordizmin 'sosyal devlet' krizine karşı Post Fordist yanıt olarak inşa edilen neo-liberal 'küresel kent' oluşum sürecinin irdelenmesidir.

\section{Kapitalizm ve Mekân İlişkisi}

'Mekân' kapitalizmin hem kendini var etmek hem de farklı dönemler ve süreçlerde kendi çıkarına bir dünya yaratmak için 'yeniden ve yeniden' yapılandırabildiği, şekillendirilebildiği bir olgudur. Sermaye her zaman ucuz emeğe ve ham maddeye yakın olmak ister; çünkü emeğin ve ham maddenin 
ucuz olduğu, ulaşımı ve erişimi kolay yerlerde yatırım yapmak sermayenin maliyetini azaltmakta ve kârını

arttırmaktadır. Tek güdüsü 'kâr' olan sermaye bu yüzden emeğin ve ham maddenin bol ve ucuz olduğu yerleri keşfetmek, kontrolünü ele geçirmek ve ihtiyacına uygun düzenlemeler yapmak eğilimindedir. Geçmişte bu ele geçirme kolonileştirme yoluyla sömürgeleştirilen ülkelerin doğal zenginliklerine ve emeğine 'doğrudan el koyma' şeklinde gerçekleşmekteydi. Günümüzde ise, 'gelişmekte olan' ya da 'geleneksel' yapılarını hala koruyan toplumsal formasyonların, diğer bir deyişle azgelişmiş veya gelişmekte olan ülkelerin ticaret yoluyla veya borçlandırılarak 'global pazara eklemlenmesi' ve bu şekilde doğal zenginliklerinin ve emeğinin sömürülmesi şeklinde gerçekleşmektedir. Kapitalizm bu anlamda sömürgeci ve yayılmacı özellikler taşıyan bir sistemdir. Sermaye kendini yeniden üretmek ve büyümek için kullandığı diğer her şey gibi coğrafya, bölge, mekânı da kullanmakta ve dönüştürmektedir. Ülkelerin, coğrafyaların, bölgelerin kontrolünü ele geçirmekte, onları kendi çıkar ve ihtiyaçları doğrultusunda yeniden şekillendirmektedir. Bu uğurda siyasi sistemlere müdahale etmekte, iktidarları devirmekte, rejimleri yeniden yapılandırmakta, gerekirse devletler yıkıp, yeni devletler kurdurtmaktadır. David Harvey kapitalizmin 'uzam ve mekân' ile arasındaki bu dinamik ilişkiyi şöyle açıklamaktadır: 'Kapitalizm 'uzamsal çözümler' bulmadan yapamaz. Krizlerine, çıkmazlarına kısmi çözüm babında ara ara yeni coğrafi düzenlemelere gitmiştir. Hem genişlemiş hem faaliyetlerini yoğunlaştırmıştır. O halde kapitalizm, kendi imajına uygun bir coğrafyayı sürekli olarak yeniden inşa eder. Tarihin belli bir aşamasında sermaye birikimini kolaylaştırmak için belli coğrafi profiller, ulaşım ve iletişim için üretilmiş alanlar, alt yapısal ve uzamsal örgütler üretir. Sonra bunları alaşağı eder; daha ileri bir safhadaki birikime yol açmak için yeniden düzenler” (Harvey, 2008a:75).Harvey de Castell gibi mekanı bir araştırma nesnesi olarak ele alan ilk kuramcılar arasında yer almaktadır. Harvey mekânın toplumsal niteliğini öne çıkarırken onun ontolojik bir kategori olmayıp, hem insanı biçimlendiren hem de insan tarafından biçimlendirilen bir toplumsal boyutunun olduğunu vurgulamakta, bu bağlamda mekânsal biçimlerin toplumsal süreçleri içerdiğini ve toplumsal süreçlerin de mekânsal olduğunu belirtmektedir (Katznelson, 2003: 10,11). Daha önceki mekân anlayışından farklı olarak kuramsal yaklaşımında 'ilişkisel mekân' anlayışını benimseyen Harvey, bu yaklaşımın bir sonucu olarak kentsel mekânı asıl olarak sermaye dolaşım sürecinde oynadığ 
toplumsal ilişki olarak sermayenin kentsel mekânın üretimi, dönüşümü ve yeniden-üretiminde oynadığı rolün, kentsel mekânın sermaye birikim süreçlerinde oynadığı rolle karşılıklılık özelliğinin olduğunu belirtmektedir. Harvey'nin "kentlerimizi üretirken kendimizi de üretiriz" ifadesi bu ilişkisel boyuta belirleyici olmasa da vurgulayıcı bir niteliğe sahiptir (Harvey, 2008a: 196). Sonuç olarak Harvey Marksist yaklaşımın "kent mekanının kapitalist üretim ilişkileri ve sermaye birikim sürecince belirlendiği” anlayışını kabul etmektedir. Yani "coğrafi mekânların kapitalist üretim ilişkileri ve sermaye birikim sürecinin tarihsel, somut ve yerel bir yansıması mı yoksa kendine özgü dinamikleri olan bir süreç veya alanlar mı olduğu” çerçevesine ele aldığ 1 'kent' sorunsalına yaklaşımı "somut coğrafi mekânların kendine özgü toplumsal ve politik dinamikleri olmakla beraber esas olarak kent mekânlarının dönüşümünde evrensel kapitalist sermaye birikim süreçlerinin belirleyici olduğu" yönündedir (Harvey, 1994:78).

Castells'e göre 'mekân' etrafındaki diğer maddi unsurlarla ilişkisi bulunan 'maddi bir üretim' olup, bu üretim sürecinde insan ise, diğer her şeyle birlikte mekâna form, şekil, nitelik ve anlam veren belli başlı sosyal ilişkiler içerisinde yer alan bir konumda bulunmaktadır. Bu anlamda mekân salt toplumsal yapıların açıklanmasına bir olanak yaratmamakta, aynı zamanda belirli bir toplumun tarihsel birliğinin somut ifadesi de olmaktadır (Castells, 1977:115). Lefebvre ve diğer yapısalcılardan farklı olarak, kendi kent kuramında esas olarak 'emek gücünün yeniden üretimi' üzerinde yoğunlaşan Castells, bu noktada Gottdiener'in de eleştirilerine maruz kalmıştır: “Gottdiener, Lefebvre'de mekânın kapitalist toplumsal ilişkilerin hem sonucu hem de yaratıcısı olduğunu belirtir ve Castells'te mekân yalnızca emek-gücünün yeniden üretildiği alandır (Castells, 2001:254). Yani Castells'a göre 'kent' kapitalist ilişkilerin sürekliliğinin sağlanması için yeniden üretilen bir mekân değil, işgücünün yeniden üretildiği 'kılıf'olarak mekândır(Gottdiener'den aktaran Sönmez, 2012: 40). Castells'e yönelik asıl eleştiri, devletin kapitalist bir mekân örgütlenmesinde oynadığ rolü ihmal etmesi üzerinedir. Çünkü Gottdiener Castells”'in aksine Lefebvre'de, toplumsal mekânın ve derli toplu bir kent biçiminin yıkılmasından sorumlu olanın bizzat devlet olduğu görüşünü ön plânda tutmaktadır. Castells ve Harvey'nin kent kuramlarını ayrıntılı olarak irdeleyen Sönmez ise iki kuramcı arasındaki karşılaştırmayı şöyle yapmaktadır:“Öncelikle ikisinin de odağında kentin ekonomik süreçlerle olan ilişkisi vardır. Harvey kapitalist sistemde kentsel mekânın organizasyonu sürecini sermaye boyutunu ön plâna çıkartarak 
ele alırken, Castells emek-gücünün yeniden-üretimi üzerinde durmaktadır. Kentsel mekânın kapitalist üretim ilişkileri içerisinde belirli toplumsal, ekonomik ve siyasal süreçler çerçevesinde nasıl organize olduğu, bu süreçte sermaye birikim koşullarının ve emeğin yeniden-üretimine yönelik ekonomik ve siyasal projelerin hangi mantığı içerdiği sorgulanan temel konulardır (Sönmez, 2012: 41). Bu durumda Söznmez'e göre Harvey sermaye dolaşım sürecinin kentsel mekânla ilişkisini kurarken, Castells kollektif tüketimin ve dolayısıyla emek-gücünün yeniden-üretiminin uğrağı olarak kentsel mekânı görmektedir. Lefvebre ile Castell ve Harvey karşılaştırması bu şekilde yapıldıktan sonra, Lefverbe'nin kendi görüşleri üzerinde biraz daha detaylı durulursa, Simonsen, Lefebvre'de mekânın hem üreten hem üretilen olmak üzere iki farklı işlevinin olduğunu belirtmektedir. Ürün olan mekânın esasen 'birincil doğa' üzerindeki toplumsal pratikler tarafından belirlenen 'ikincil bir doğa' olarak ele alınması gerekmektedir. Burada 'birincil doğa' bizzat üretim süreci ve ilişkileri ile bütünleşen mekân olarak kenti, 'ikinci doğa' ise bir şey ya da basit bir nesne olmaktan öte bu üretim ilişkilerinin bir ürünü olan kenti ifade etmektedir (Simonsen, 1992: 81). 'Kent' olgusunu kapitalist üretim ilişkileri ile etkileşim içinde sürekli değişiklikler gösteren, kapitalizmin farklı dönemlerinde, dönemin üretim koşullarına ve sermayenin ihtiyaçlarına göre sürekli farklılaşan, dönüşen dinamik bir süreç olarak değerlendiren Lefebvre özellikle endüstriyel kentin inşasından bahsederken 'kentin yeniden inşası' söz konusu olduğunda eski kentin yıkılması gereği üzerinde durarak, bunu aynen Marx ve Engels'te olduğu gibi kapitalizmin yıkıcılı̆̆ının yapıcı etkisi olarak ifade etmektedir. Bu arada Lefebvre'nin kentin yıkılması ile kentselliğin artması arasındaki çelişki üzerine inşa ettiği görüşünde bahsettiği 'kentsel etkinlik' konusu Harvey'de ise 'yaratıcı yıkıcılık' şeklinde yorumlanmaktadır. Buna göre kent, mekânda bulunan objelerin bir düzenlemesi, kentsellik ise, bir yaşam biçimidir (Aktaran: Özdemir, 2010: 62). Nihayetinde Harvey (2003: 187), Lefebvre'in de etkisinde kalarak şu çözümlemeyi yapmaktadır: 'Kent kısmen, önceki üretimde biriktirilmiş sabit varlıkların bir deposudur. Belli bir teknoloji kullanılarak inşa edilmiş ve belli bir üretim tarzı bağlamında yapılandırılmıştır. Kentsellik bir toplumsal biçim, diğer başka şeylerin yanında belli bir işbölümüne ve egemen üretim tarzıyla genelde tutarlı, belli bir hiyerarşik faaliyet düzenine dayandırılmış bir yaşam tarzıdır" (Harvey, 2003: 18). Kentsellik ve kentin, belli bir üretim tarzını dengede tutma işlevi bulunmakla birlikte aynı zamanda kent biriken çelişkilerin de odağı durumundadır. Ayrıca yeni bir üretim tarzının 
da muhtemel doğum yerini oluşturmaktadır. Tarihsel olarak kent, etrafında belli bir üretim tarzının örgütlendiği bir eksen, kurulu düzene karşı bir devrim merkezi ve (kendisine karşı isyan edilen) bir güç ve ayrıcalıklar merkezi olarak görülmektedir. Kent ve kırsal kesim arasındaki antitez ise etrafinda toplumun tüm iktisadi tarihinin geliştiği bir hareket ve çatışma eksenidir(Aktaran: Özdemir, 2010: 59,60).

Kapitalizmde mekân ilişkisi, öncelikle feodal sistemden kapitalizme geçişte burjuva devriminin kentlerde gerçekleşme süreciyle başlamaktadır. $\mathrm{Bu}$ arada 'kent' olgusu, yukarıdaki ifadelerde de açıklandığı üzere, özellikle yeni marksist yaklaşımlarda, gerek içerik gerekse işlevsel olarak kapitalizmin farklı dönemlerinde farklı özellikler gösteren, sermaye ve kapitalist üretim ilişkileri açısından her zaman önemini koruyan dinamik bir süreç olarak ele alınmaktadır. Kapitalizmin bugünkü aşamasında mekânın -her ne kadar yerel, bölgesel, küresel ve kentsel olarak bir ayrıştırmaya tabi tutuluyor olsa dahi- bütün olarak ifade edildiği anlamıyla 'yaşam alanlarının' kapitalist sermaye birikimi açısından oldukça farklı, yaşamsal bir işlevi bulunmaktadır. Özellikle de neoliberal dönemde içeriği önemli ölçüde değişen 'kent' olgusu ve 'küresel kent' kavramıyla oldukça esnek ve karmaşık bir süreçten söz edilmektedir. Bugün artık 'kent' kapitalist üretim sürecinin sadece gerçekleştiği 'fiziki çevre' olmaktan dolayı müdahaleye uğrayan, değişen, dönüşen bir olgu olmaktan çıkmış, bizzat sermaye birikimini sağlamanın bir aracı, 'kaynağı' haline gelmiştir. Günümüzde artık zenginliğin, 'zenginleşmenin yolu' kent ve doğanın büyük bir hızla metalaştırılarak, 'ticari amaçla' yeniden yapılandırılması ve ustaca pazarlanmasından geçmektedir. Dolayısıyla 'sermaye birikimi' bizzat kent ve doğa üzerinden elde edilen artı-değer ve yine kent ve doğada (kırsal kesimde) üretilen hizmetlerden sağlanmaktadır. Sermaye birikiminin temel kaynağ 1 'doğa' ve 'kent' olunca, başlıca işlevi mevcut sermaye birikimin önündeki engelleri kaldırmak ve gerekli yasal alt yapıyı oluşturmak olan neoliberal kır-kent politikaların işlevi de günümüz sermaye birikiminin başat aktörü olan inşaat sermayesinin ve faaliyetlerinin önünü açmak; doğa ve kenti savunmasız hale getirecek uygulamaların, müdahalelerin önündeki yasal engelleri kaldırmak; daha önce denetleme yetkisi olan kurum ve kurulları etkisiz hale getirmek ve hızla gerekli görülen imar değişikliklerinin önünü açan yasal alt yapıyı hazırlamak olmaktadır. Örneğin Türkiye' de son 10 yıllık dönemde, bu konuda sadece inşaat firmaları ve müteahhitlerin ihtiyaçlarını karşılayan 'özel bir hukuk alanı’ oluşturulmuştur. Başta tarihi sit alanları olmak üzere 
(Anayasanın 5366 nolu maddesi ile) kentsel ve kırsal alanların, tarihi ve arkeolojik alanların, ormanların, yeşil alanların, tarla ve su havzalarının, sahillerin, parkların, yaylaların imar ve inşaata açılması; bu konudaki denetim mekanizmalarının esnekleştirilmesi; kurum ve uzman kuruluşların, üniversitelerin, meslek odalarının etkisiz hale getirilmesi, bütün bu yasal düzenlemeler ve yeniden yapılandırma süreçleri günümüze ait neo-liberal kırkent politikalarının bir sonucudur. Yine 6306 nolu 'Afet yasası' ile inşaat sermayesini işini kolaylaştırmak amacıyla bireylerin mülkiyet ve tapu hakkını kısıtlamak pahasına 'acele kamulaştırma' yapmanın önünün açılması, ayrıca normalde savaş halinde işgalci ülkenin işgal ettiği yerin elektrik ve suyunu kesme yoluyla yaşamın sürdürülebilirliğini kısıtlaması uluslararası yasalarca 'savaş suçu' sayılırken, Tükiye'de bu madde Afet yasasının içine sokularak yasallaştırılmıştır. Amaç yukarıda da vurgulandığı üzere, kır, kent, bölge olarak tüm yaşam alanlarının 'özelleştirme' ve ‘ticarileştirilme' yoluyla sermaye birikimine katkı sağlamak üzere sermayenin kontrolüne geçmesidir. Bugün artık 'mekân' odaklı bu politikalar tüm kapitalist ülkelerde uygulanmakta olup 'kentsel dönüşüme dayalı sermaye birikim modeli' diğer bir deyişle 'inşaat ve hizmet odaklı büyüme modeli’ küresel ölçekte yaygınlaşmaktadır.

\section{Kapitalizmden Tamamen Bağımsız Bir mekân Üretimi Mümkün Müdür?}

Robert Park'1n deyimiyle 'insanlar kentlerini üretirken kendilerini de yeniden üretmektedirler: "Kent aynı zamanda "insanın içinde yaşadığı dünyayı daha çok gönlüne göre yeniden yapmada en başarılı girişimidir. Ama eğer kent insanın yarattığı dünyaysa bundan böyle orada yaşamaya mahkûm olduğu dünyadır da. Öyleyse insan kenti inşa ederken, dolaylı olarak kendini de yeniden inşa etmektedir(Park, 1967: 3). Kent ve kentli arasındaki ilişkiyi karşılıklı etkileşim içinde bulunulan dinamik bir süreç olarak değerlendiren ve bu konuda Marx'ın diyalektik yöntemini referans alan Harvey, yukarıda Park'ın da değindiği 'kendimizi yeniden inşa etme sürecini' 'kent hakkı' kapsamında en kıymetli insan haklarından biri olarak değerlendirmektedir (Harvey, 2004: 236-239). Harvey'e göre tüm insan emeğinin kökeninde bir diyalektik bulunmaktadır. Diyalektiğin bir tarafında tahayyül ve irademizi kullanarak bireysel ve kolektif olarak günlük eylemlerimiz, politik, entelektüel, ekonomik aidiyetlerimiz aracılığıyla kenti inşa ederiz. Ama karşılık olarak, kent de bizi inşa eder. Böylece alternatif kentsel dünyalar hayal etmek olanağımız doğar. 
Ancak bu bütün hayallerimizi gerçekleştirebileceğimiz anlamına gelmemektedir. Bunun sınırını çizen yine 'üretim ilişkileri' ve 'birikim' koşullarıdır. Yani altyapıdır. Burada gözden kaçırılmaması gereken nokta, ne kadar yaşadığımız 'kent' ve sunduğu imkanlar bizim nasıl bir insan olacağımız konusunda önemli etkiye sahip olup, 'bizi inşa etme potansiyeli' taşısa da, son kertede dolaylı yoldan da olsa kenti de asıl belirleyenin yine 'üretim ilişkileri' ve sermaye birikim koşullarının olmasıdır.

Aslında geçmişten günümüze 'insanların kendi kentlerini kendilerinin oluşturabileceği' görüşünden yola çıkılarak üretilen birçok 'Kent ütopyası' bulunmaktadır ve bunların bir bölümü hayata geçirilmeye de çalış1lmıştır. Kapitalizmin sınıfsal ve mekânsal ayrışma yaratan, ülke, bölge ve kent kaynaklarını belli bir ayrıcalıklı sınıfın lehine eşitsiz şekilde paylaştıran yapısı yüzünden bu uygulamalar istenilen başarıya ulaşmamıştır. Örneğin Fishman'ın 'Burjuva Ütopyaları' eseri (Fishman, 1987); Gans'ın 'Levitowners'i (Gans, 1996); Howard'ın 'Geleceğin Bahçe Şehirleri' (Howard, 1996) bu tür 'ütopik kent' tasarımlarına örnek teşkil edecek önemli çalışmalardır. Bu çalışmalar aynı zamanda kentin 'mekansal ayrışma' ve 'alt-kentler' olgusunun tartışılmasında önemli referans kaynaklarını oluşturmaktadır. Özellikle Gans'ın burjuva ütopyasından sonra Amerikan rüyasının savaş sonrası versiyonu olarak sunulan alt-kentlerin aslında orta sınıflar için bir 'rüya' olmadığ1 ve ütopyacı kent tasarımlarının uygulamada beklenildiği gibi başarıyla sonuçlanmadığı şeklindeki değerlendirmeleri de buna örnek verilebilir. Dolaysıyla Park'ın 'kentini yaparak insan kendini yeniden yapmaktadır" görüşü kısmen kabul edilebilir olmakla birlikte, yukarıda da altı çizildiği üzere 'kenti tasarlama' konusunda nispeten daha özgür olan bireyin, 'kenti inşa etme' konusunda aynı derecede özgür ve başarılı olmadığı, bu konuda kapitalizmin değişmez yasalarına ve temel dinamiklerine tabii olduğu görülmektedir. Özellikle yukarıda ‘kapitalizm' ve ‘mekân' ilişkisinde açıklandığı üzere, üretim ilişkileri ve sermayenin kendini yeniden üretme koşulları bütün coğrafya, bölge ve mekânı, Harvey’in deyimiyle de uzamı belirleme gücüne sahiptir. Diğer bir deyişle kapitalist üretim ilişkilerinden bağımsız bir kent üretimi veya yapılanması bu durumda bu yaklaşımda mümkün değildir. Kent gerçekten de ütopyacı görüşlerde olduğu gibi mimarların kafalarında ürettikleri bağımsız bir tasarım değildir; en azından böyle bir özgürlük kapitalist sistemde yoktur. Kapitalist sistemde diğer bütün 'üst-yapı' kurumları ve oluşumlarının olduğu gibi kentin oluşum ve dönüşüm 
süreçleri de aynı sermaye birikim yasalarına ve 'üretim koşullarına' tabidir. Söz konusu olan 'bölge' olabilir, 'kır-kent' olabilir; önemli olan sermayenin kendini yeniden üretme sürecinde ihtiyaç duyduğu her şeyi, doğal yaşamı, çevreyi, coğrafyayı, mekânı, bütün yaşam alanlarını çıkarlarına göre değiştirme/dönüştürme gücüne sahip olmasıdır. Kapitalizmin bu belirleyici özelliği göz önünde bulundurulduğunda, dönemsel olarak her kapitalist safhada kentin hangi kısmında hangi nüfusun yoğunlaşacağ 1 ; kentsel alanların farklı sınıflar ve iş yerleri arasında nasıl paylaşılacağı; kentin kamusal ve özel alanlar olarak nasıl inşa edileceği, bunun sonucunda ne tür 'sınıfsal ve mekânsal' ayrışmalar yaşanacağı konuları, kapitalist üretim ilişkileri ve egemen güç ilişkilerinden bağımsız düşünülmemelidir. Harvey sermayenin bu dönüştürücü gücünü şöyle vurgulamaktadır: "Sermaye bir süreçtir, bir şey değil. Toplumsal hayatın meta üretimi aracılığıyla yeniden üretim sürecidir. Gelişmiş kapitalist ülkelerde yaşayanlar olarak hepimiz bu sürecin bir parçasıyız. Sermayenin içselleşmiş işleyiş kuralları, içinde kökleştiği toplumu hiç durmaksızın, sürekli olarak dönüştüren dinamik ve devrimci bir toplumsal organizasyon tarzı olmasını sağlayacak bir yapıya sahiptir. Süreç perdeler ve fetişleştirir, büyümeyi yaratıcı yok etme aracılığıyla sağlar, yeni ihtiyaç ve istekler yaratır, insanın emek kapasitesini ve arzuyu sömürür, mekânları dönüştürür" (Harvey, 1997: 376).

\section{Kapitalizm mekân Artı-Değer ve Sermaye Birikim Sürecinde Kentler}

Kapitalizm sermaye birikimine ve kâra (artı-değere) dayalı bir sistemdir. Bu bağlamda kâr(art1-değer) elde etmek sistemin olmazsa olmaz koşuludur. Bunun dişında diğer her şey değişebilmekte, dönüşebilmekte, ikame edilebilmektedir. Kârın (artı-değerin) elde ediliş koşulları, yöntemleri bir kapitalist safhadan diğerine değişebilmektedir. Farklı kapitalist sermaye birikim rejimlerinde farklı uygulamalar, yöntemler kullanılmaktadır. Bu yüzden kapitalizmde her krizden sonra farklı bir 'sermaye birikim rejimi' ve farklı bir kapitalist dönemden bahsetmek mümkündür. Kapitalizminin 'doğa', 'insan', 'kent' ve 'yaşam' ilişkisine bakıldığında bugün dünden çok daha tahrip edici bir yaklaşım sergilendiği görülmektedir. Kapitalizm her zaman başta insan olmak üzere, doğaya, çevreye, kente, yaşama müdahale etmiş, çıkarları doğrultusunda düzenlemeler yapmış gerektiğinde zarar vermekten, yok etmekten, kaçınmamıştır. 'Küresel kapitalizm', ülke veya bölge üzerinde bulunan 'küresel kentler'l 'küresel pazar'a eklemlenme yoluyla sermaye birikiminin sağlandığı 
yeni bir kapitalist birikim rejimidir. 'Sermaye birikimi' emek üzerinden 'art1değer’ elde etme yoluyla sağlanabilmektedir. Bu anlamda kapitalizmin varlığını sürdürebilmesi ve sermaye birikiminin kesintisiz sürmesi için sistemin sürekli olarak art1-değer üretmesi (Kâr etmesi) gerekmektedir. Eğer art1-değer kesintiye uğrarsa, yani sermaye kâr edemez hale gelirse, sistem krize girecektir. Bu nedenle kriz genellikle, kapitalizmin yapısal özelliklerinden biri olan 'kâr haddinde düşme eğilimi’ ya da 'eksik talep' krizi olarak kendini göstermektedir. Kâr haddinde düşüşle birlikte sermaye birikimi yavaşlar, üretim döngüsü tamamlanamadığg için sermaye birikimi kesintiye uğrar ve "kriz” gerçekleşir. Eğer yapılan müdahale ve düzenlemeler sonucu sistem tekrar kâra geçmezse bu kapitalizmin sonu olur.

Kapitalizmde 'kâr' olgusu değişmese de, kârın elde ediliş yöntemleri, koşulları, diğer bir deyişle 'sermaye birikim rejimi' ve 'düzenleme tarz'ı her yeni kapitalist safhaya geçerken krizin etkisiyle değişebilir, dönüşebilir. Örneğin Fordizmin ulusal pazarlara yönelik büyük fabrika sistemi ve özel amaçlı tek tip mal üreten makineleri; vasıfsız emek kullanılarak gerçekleştirdiği seri üretimi ve buna göre gerçekleşen hiyerarşik örgütlenme biçimi Post Fordist süreçte küreselleşme olgusuyla birlikte tamamen değişmektedir. Bu süreçte daha küçük ve esnek üretim birimleri; esnek teknolojiler, zevk ve tercihlerin değişmesiyle ortaya çıkan talep çeşitliliğine uyum sağlayacak şekilde çok işlevli esnek makineler; vasıflı, vasıfsız ve yarı vasıflı olarak parçalanmış emek; mekân olarak da Fordizmin 'ulusal' pazarlarının yerini 'küresel kentler' in aldığı ve piyasaların 'küresel pazar'a 'küresel kentler' aracılığıyla eklemlendiği yerel/ bölgesel yeni bir 'üretim biçimi' söz konusudur. Bu arada Fordizmin 'kitlesel pazar'lar için 'kitlesel Üretim' şeklinde gerçekleşen 'üretim döngüsü' Post Fordist süreçte zevk ve tercihlerin sürekli değiştiği talep çeşitlenmesine göre farklı ürünlerin farklı parçalarının farklı yerlerde üretildiği 'parçalanmış' bir üretim döngüsüne dönüşmektedir. Sermaye artık 'ulusal' pazarlardan çıkarak uluslararası alanda 'küresel' düzeyde serbestçe hareket edebilen bir nitelik kazanmıştır. Ulusal pazarlara dayalı üretimin tıkandığı yerde küresel/bölgesel ölçekli yeni bir 'sermaye birikim rejimi'ne geçilmiştir. Buna göre günümüzdeki 'neo-liberal kent politikaları' ve stratejilerinin öncelikli amacı, kentin küresel sermayenin ihtiyaç ve beklentilerine göre 'yeniden yapılandırılması', bu konuda gerekli yasal değişikliklerin ve düzenlemelerin yapılması ve uygulamada ortaya çıkacak mağduriyet ve hak ihlallerini gizleyecek 'meşrulaştırıcı' bir neo-liberal bir söylemin oluşturulmasıdır. Türkiye’de daha önce yukarıda da değindiğimiz 
5366 ve 6306 gibi inşaat ve imara dayalı bazı düzenlemeler bu amaca hizmet etmektedirler.

\section{Kapitalizmde Fordist Dönem ve Fordizmin Sanayi/İşçi Kentinin Oluşumunu Belirleyen Temel Yasalar}

Çalışmanın başında da belirtildiği üzere, kapitalizm, kendini yeniden üretme sürecinde, başta 'doğa' ve 'toplumsal yaşam' olmak üzere etkileşimde bulunduğu her şeyi, çevreyi, nesneleri, insan ilişkilerini değiştirmekte, dönüştürmektedir. Bu dönüşüme üretim ilişkilerinin gerçekleştiği 'coğrafya', 'bölge', 'mekân' da dahildir. Sermaye birikim sürecinde, özellikle de günümüzde 'kent', hem üretim ilişkilerinin içinde gerçekleştiği yer olma özelliğine sahip olması bakımından hem de kapitalizmin metalaştırarak kullandığı bir birikim kaynağına dönüşmesi açısından oldukça önemli bir yere sahiptir. Kent, kapitalizmin her safhasında fiziki ve sosyo-ekonomik koşullarıyla dönemden döneme farklılaşmakta, kapitalizmin her yeni safhasında gerek işlevsel gerekse yapısal olarak farklı bir formda, farklı bir toplumsal işbölümü ve örgütlenme, sınıfsal ve mekansal ayrışma ile karşımıza çıkmaktadır. Giriş bölümünde de ifade edildiği üzere bu çalışmanın amacı kapitalizmin farklı dönemlerinde kentte gerçekleşen değişim ve dönüşüm süreçleri ile kapitalist üretim ilişkilerinin bağlantısını kurmak, bunu da özellikle iki farklı kapitalist dönemi baz alarak, Fordist ve Post Fordist safhada, bir dönemden diğer döneme geçişte ortaya çıkan temel dinamikleri irdeleyerek yapmaktır. İlgili bölümde belirtildiği üzere kapitalizm kâra dayalı bir 'sermaye birikim sistemine sahiptir. Sermaye birikiminin kaynağını oluşturan kâr (artı-değer), esas olarak iki şekilde, 'mutlak artı-değer' ve 'nispi art1-değer' yoluyla elde edilmektedir. Mutlak artı-değer çıplak emek sömürüsüne, yani doğrudan ücretlerin düşürülmesiyle sağlanan emek sömürüsüne, nispi artı değer ise teknolojik gelişme ve verimlilik artışı sayesinde gerçekleşen dolaylı yoldan emek sömürüsüne dayanmaktadır. Kapitalizm Fordizm öncesi dönemde teknolojik gelişme ve verimlilik artışına dayalı bir birikim sistemi henüz gerçekleşmediği için, direk canlı emek sömürüsüne (mutlak artı-değere) dayalı bir sermaye birikim rejimine sahipti. 'Kâr uzun çalışma saatlerine ve işçilerin ücretlerinin baskılanarak düşük tutulmasına bağlıydı. Süreç içinde bu yoğun emek sömürüsü sayesinde çok önemli oranda sermaye birikimine ulaşıldı ve teknolojinin de gelişmesiyle üretim verimliliğinde yüksek artışlar kaydedildi. Bununla birlikte işçi ücretlerinde hiçbir düzenleme yapılmadan mutlak artıdeğere dayalı birikim rejiminin 'rekabetçi' düzenlemeleri aynen devam ettiği 
için, işçilerin alım gücünde çok önemli düşüşler oldu. $\mathrm{Bu}$, sermaye birikimindeki aşırı artışla ters orantılı bir düşüştü. Sonunda sistem aşırı 'sermaye birikimine karşı 'sermayenin değersizleşmesi' yetersiz' kalan 'eksik talep krizi' ile tıkand1 ve '1929 dünya krizi' gerçekleşti. Fordist birikim rejimi bu açıdan, önceki dönem hakim olan mutlak artı-değere dayalı yaygın sermaye birikim rejiminin karşı karşıya olduğu 1929 dünya krizine kapitalizmin bulduğu '‘̧özüm' veya 'yanıt' olarak da düşünülebilir. Bu süreçte ağırlıklı olarak istihdam ve talep yönetimine dayalı Keynesyen politikaların hakim olduğu yeni bir kapitalist safhaya geçilmiştir. Aşırı sermaye birikimine karşı eksik kalan talep koşullarına, çalışma hayatında gerçekleşen pozitif düzenlemeler, toplumun geneline iş ve gelir sağlamayı amaçlayan tam istihdam politikaları ve işçilerin yaşam koşulları ve ücretlerinde gerçekleşen iyileştirmelerle yanıt verilmek istenmiştir. $\mathrm{Bu}$ dönemde işçilerin çalışma koşulları ve yaşam düzeylerinde daha önce görülmemiş düzeyde iyileşmeler kaydedilmiştir. İşçilerin sendikalaşmaları desteklenmiş; emekçi kesime birçok ekonomik ve sosyal haklar verilmiş; toplumsal yaşamda ve özellikle kent yaşamında 'kamusal alan' ve 'kamusal hizmetlere erişimde' daha adaletli, daha eşitlikçi bir yaklaşım benimsenmiştir. Krizin dayatması sonucu 'sermaye' elde ettiği pastadan emekçi kesime önemli oranda pay verme konusunda işçi sınıfı ile uzlaşmak zorunda kalmış, bu sayede hem sermaye birikiminin önünü tıkayan 'kriz' engeli aşılmış hem de tüm sınıflar açısından dünya çapında yüksek düzeyde bir toplumsal refahın gerçekleştiği görülmüştür. Bu uzlaşmadan iki taraf da kazançlı çıkmıştır. Bu dönem literatürde 'kapitalizmin altın çağı' ya da , 'refah dönemi' olarak anılmaktadır.

Fordist birikim eejiminin başlıca özellikleri şöyledir: Kitlesel üretime karşılık gelen kitlesel talep yönetimi; Taylorist sanayi örgütlenmesinin hakim olduğu, otomasyona bağlı büyük fabrika sistemi; standart ürünlerin üretildiği, üretimin ulusal pazarlar için yapıldığı ve emek gücünün daha çok yarı vasıflı işçilerden oluştuğu tekelci bir devlet kapitalizmi. Bu özellikler Allen tarafından maddeler halinde biraz daha detaylı olarak şöyle ifade edilmektedir: “ 1) standartlaşmış parçaların birleşimi, özel amaçlı makineler ve hareketli kayan montaj bandı üzerinde üretim, üretimde genel olarak standartlaşma; 2) ölçek ekonomisi ile büyük ölçekte kitlesel üretim; ulusal pazarların korunduğu sisteme bağlı standartlaşmış uzun ömürlü mallar; 3) Büyük fabrikalarda yüksek ücretle istihdam edilen yarı vasıflı işçi yığınları; 4) Merkezi yönetim tarafindan belirlenen hiyerarşik, bürokratik iş organizasyonu; 5) Gelir, talep ve refah düzeyinin Keynesyen politikalarla ayarlandığı ulusal ekonomi politikaları; 6) 
Tüm üretim sürecinin kitlesel üretime bağlı kitlesel tüketime dayanması” (Allen, 1993: 185). Fordizm'de devlet her konuda tek karar verici olarak ülkeye, siyasete ve ekonomiye hakimdir. Toplumsal yaşamın planlanması, tüm kurumsal yapıların oluşturulması, iç-dış bütün politikaların belirlenmesi, her türlü üretim ve toplumsal ilişki ağlarının kurulması, yönetilmesi, yönlendirilmesinde başlıca yetkilidir. Bununla birlikte 'üretim ilişkileri' alt-yapı olarak ele alınırsa, 'altyapı üst- yapıyı belirler' yaklaşımı çerçevesinde, bir 'üst-yapı' kurumu olarak devlet, bütün bu düzenleyici gücüne rağmen yine de kapitalist üretim ilişkileri tarafından 'belirlenme' durumunu korumaktadır; yani hem düzenleyen hem düzenlenen konumundadır. Diğer bir deyişle devlet, kendisi Fordist döneme özgü 'tekelci' gücüyle bütün politika ve oluşumların, değişim ve dönüşümlerin karar vericisi, düzenleyicisi konumunda olmasına rağmen, kapitalist üretim ilişkilerine ve sermaye birikim koşullarına tabiiyeti nedeniyle aynı zamanda düzenlenen konumundadır da.

Fordist dönemde, 19.yy Liberalizminin piyasa belirleyiciliğine karşı 'ikinci endüstri devrimi'nin yeni kapitalizminin piyasalara artık bu otonomiyi tanımadığını; politik ekonomistler tarafından kuralları belirlenmiş olan Laissezfaire sisteminin artık sürdürülemez olduğunu; kapitalizmin ölçeği ve menzili gerek yerel gerek uluslararası düzeyde genişledikçe devletin piyasaların işleyiş şartlarını, tarife ve vergi politikalarını artık kendisinin düzenlemeye başladığını belirten Katznelson, devletin bu dönemdeki kentlerle ilgili düzenlemelerini şöyle özetlemektedir: "Devlet ve kapitalizmin ilişkisinin bu değişen örgünün ayrılmaz yönleri olarak kentlerdeki hükumetler, mekanı, birikim ve vatandaşlığın çatışan haklarının tesis ettiği gerilim alanı içinde biçimlendirmeye başladılar. Kentin büyümesi giderek sermaye mantığının direkt bir dayatması sorunu olmaktan çıkıp, daha çok planlanmış devlet müdahalelerinin bir ürünü olmaya başladı. Yol yapımı, varoşların yıkılması, sıhhi tesisatın ve su altyapısının sağlanması ve bunun gibi hizmetler politikleşti ve bütün farklı sosyal sınıfların önem verdiği noktalar haline geldi” (Ketznelson, 2019: 307). Katzelson ayrıca bu dönemde İşçi sınıfı ve sermaye sınıfının mekansal olarak farklılaşmaya başladığını, özellikle ev ve iş yeri ayrımının iyice belirginleşmesiyle sermayenin iş yerlerinin yoğunlaştığı iş̧̧i bölgelerinden uzakta yaşamayı tercih ettiğini, özellikle endüstri devriminin gerçekleştiği İngiltere'den Lancashire bölgesini örnek alarak anlatmaktadır: "Lanashire' deki el işi sisteminin yok olmasının, endüstriyel devrim içinde ev üretiminin daha genel olarak tasfiyesi gibi, mekansal sonuçları çok sayıda temeldi. Fabrika yöneticilerinin işçi sınıfı 
hayatının tamamına hakim olduğu şirket kasabaları dışında kapitalistlerin rolü işyeri ile sınırlıydı ve bu işçilerin konut alanlarında direkt bir denetimden uzak, özgür yaşamalarını sağlıyordu”' (Katzelson, 2019:246). Katzelson'un yukarıdaki ifadeleri bu makale kapsamında savunulan iki temel tezi destekler niteliktedir: Hem üretim ilişkileri ve sermaye birikiminin değişen koşullarının mekanı/kenti belirlediğini, dolaysıyla her kapitalist dönemde farklı bir kent formu ve sınıf yapılanmasının söz konusu olduğunu; hem de Fordizmin sanayi kentinin ağırlıklı olarak bir 'işçi kenti' olduğu görüşümüzü doğrulamaktadır. Fordizmin işçi sınıfına sağladığı avantajlara devletin bu konudaki belirleyiciliğine gelince, başta 'sendikalaşma' ve 'toplu sözleşme hakkı' olmak üzere birçok sosyal hakkın emekçilere en geniş olanaklarla sağlandığı bu dönemde yetki ve sorumluluğu yine devlet üstleniyor, bütün düzenlemeler devlet eliyle yapılıyor, bütün kararlar devlet tarafından veriliyor, siyasi, ekonomik, toplumsal bütün politikaları devlet belirliyordu. Bu nedenle 'sosyal devlet' kavramı da literatüre bu dönemde Fordizme özgü bir kavram olarak geçiyordu. İşçilerin yaşam koşullarında çok önemli gelişmeler gerçekleşiyor, emekçi kesim tarihte hiç görülmedik şekilde bir pazarlık gücüne ve yüksek yaşam standardına sahip oluyordu. Devlet, sermaye ve emek arasındaki anlaşmazlıkların çözümünde ara buluculuk görevini üstleniyor, işçilerin çalışma şartları ve hakları, kamusal hizmetlere ve kamusal alanlara erişim olanakları, eğitim, sağlık hizmetleri ve diğer sosyal haklar yine bu dönemde en yaygın biçimde yasal güvenceye kavuşturuluyordu. Devlet her alanda büyük yetkilerle karar verici ve uygulayıcı pozisyonda bulunuyordu. Keynesyen politikaların başarıyla hayata geçirildiği bu dönemde amaç esas olarak işçilerin pazarlık ve alım gücünün arttırılması yoluyla iç pazara dayalı, her ulusal devletin kendi talebini kendisinin yarattığı, başka bir deyişle 'ulusal pazarlara dayalı' kapalı ekonomi modelinin tüm dünyada yaygınlaştığı bir süreci başlatmaktı. Berenner ve Keil ise Fordizmin özelliklerini şöyle anlatmaktaydı: "Fordizm, sanayileşmiş batı dünyasında, İkinci Dünya Savaşı'ndan 1970'lerin başlarına kadar egemen olmuş olan birikim rejimidir. Fordist modelde üretim artışı, seri üretim teknolojileri üzerinde oturmuş olup göreceli olarak işbirlikçi çalışma ilişkilerine ve yükselen işçi sınıfı gelirlerine katkı sağlayan, sermaye ve emek arasındaki sınıfsal bir anlaşma ile yakından alakalıdır. Ayrıca, yükselen işçi sınıfı gelirleri de tüketici mallarına yönelik yerli talebi sabitleyen genişlemeci refah devleti aygıtıyla pekiştirilmiştir. Uluslararasında da Fordizm, Amerikan kültürel, finansal ve askeri hegemonyasıyla düzenlenmiş ve yeniden üretilmiştir. Ve de eski 
sanayileşmiş dünya boyunca uzanan geniş ölçekli sanayi bölgelerinin etkileyici dinamizmiyle kök salmıştır” (Brenner and Keil, 2013). Gramsci’ye göre Fordist birikim rejimi, kapitalist medeniyette yeni bir dönemin başlangıcıdır. Planlı ekonomiye geçişte etkili olan ama yalnızca üretimi planlamayıp aynı zamanda bireyi de planlayan bir üretim rejimidir. Fordizm sadece fabrika kapısı önünde durmamış evi ve işçinin hayatının en özel ve mahrem alanlarını da işgal etmiştir (Gramsci: 1986;302 ) Fordist dönemde sanayileşme ile birlikte mekân da buna göre şekillenmiş, kent içerisinde yaşayan insanların yaşam tarzları bu süreçten doğrudan veya dolaylı olarak önemli ölçüde etkilenmiştir. Yani Fordist üretimin devlet yapılanması üzerinde gösterdiği etkinin yanı sıra sosyal yapıda da önemli değişikliklere yol açtığı, kendi çıkarları doğrultusunda oluşturduğu kurallara dayalı üretim sistemiyle toplumsal yapıyı da belirlediği görülmüştür. $\mathrm{Bu}$ bağlamda Ford'u Taylor'dan farklı kılan özelliği, emek gücünün kullanımı için yeni bir sistem olan kitle üretimine dayalı 'kitlesel tüketim modeli'ni uygulaması yanı sıra, bunun sonucunda gerçekleşen rasyonel, modern, popülist bir 'demokratik toplum modeli ni de oluşturmasıdır. Buradan hareketle Ford için işçilere yüksek ücret vermek yeterli olmamış onların paralarını uygun şekilde harcayacakları bir 'tüketici birey'e dönüşmelerine de katkı sağlamıştır (Aktaran: Sakl1, 2007:4)

Fordizmde devlet diğer her alanda olduğu gibi, 'kent' yapılanmasında ve kente dair verilen kararlarda da belirleyici konumdadır. Devlet planlama yoluyla kente müdahale etmekte, kent yaşamına ve yapılanmasına dair kararları bu konuda uzman kuruluşların ve yetkili kurumların görüşlerine başvurmakla birlikte yine sonuçta kendisi vermektedir. Kent alanlarının sınıflar arasında paylaştırılması, kamusal ve özel alanların belirlenmesi, kente üretilen hizmet ve olanaklara erişim hakkının hangi kriterlerle kimin için ne şekilde sağlanacağı, tüm bu kararların sahibi, belirleyicisi hep devlettir. Üretimde çeşitlilik henüz gerçekleşmemiştir. İnsanlar hayatlarında birçok malı ilk kez görmektedirler. Başta otomobil olmak üzere birçok elektronik alet ve makine insan hayatına ilk kez girmiştir. Bu arada otomobil ilk olarak Amerika'da Ford fabrikalarında üretildiği ve dönemin en belirgin özelliği olan Taylorist bant sistemi ve onun da en temel mekanizmasını oluşturan otomasyon uygulaması yine ilk kez Ford fabrikalarında kullanıldı̆̆ 1 için, kapitalizminin bu dönemine Fordizm adı verilmiştir. İşçiler bu fabrikalara yakın yerlerde, kent merkezinde inşa edilmiş ucuz konutlarda, ya da yine kentin önemli yerlerinde planlamayla oluşturulmuş sosyal konutlarda yaşamaktadırlar. O dönem sosyal politikalarla işçilerin 
ücretleri kadar yaşam koşullarının da iyileştirilmesi amaçlandığg için, barınma, eğitim ve sağlıkta işçilere her türlü olanak bizzat devlet eliyle sağlanmakta, kentin en önemli merkezlerinde, en erişilebilir yerlerinde devlet okulları, kamu hizmet binaları, kreşler, devlet hastaneleri, devlet okulları/üniversiteleri, yeşil alanlar, dinlenme/eğlenme/sosyalleşme yerleri/tesisleri bizzat halk için halk yararına (kamu yararına) devlet tarafından hayata geçirilmekteydi. Bu anlamda Fordizmin sanayi kenti gerçekten de kamu kuruluşlarının ve halka açık kamusal alanların çok sayıda olduğu, yeşil alanlar ve sosyal alanların herkes için eşit mesafede erişilebilir olduğu, kamu yararına (halk için) planlanmış mütevazi bir 'iş̧̧i kenti’ydi. Değişik meslek gruplarının kendi lojmanları, kampları, sosyal alanları, tatil için tesisleri, dinlence yerleri bulunmaktaydı. Bunların hepsi kentte planlanmış 'kamusal alanlar' anlamına gelmekteydi. , Fordizmin toplumsal özelliğinin temelini oluşturan olgulardan biri 'korporatizm' di. Bu çerçevede toplum bilimci Jessop, Fordist dönemde daha çok şirket birlikleri ve ticari birlikler çerçevesinde gerçekleşen korporatizmin, 1960 ve 1970 yıllarında yaşanan ekonomik krizlerin çözümünde önemli rol oynadığını, özellikle 'karma ekonomi’ye dayalı müdahaleci refah devletinin karşılaştığı sorunların çözümünde oldukça etkili olduğunu, 'dengeli büyüme modeli’ne dayalı bu dönemde oluşturulan gruplar arasında işbirliğinin sistemin gelişimine de önemli katkı sağladığını belirtmektedir (Aktaran: Aydınlı, 2004: 17,18). İşçi sınıfı adına tüm bu kazanımlar ve olumlu işleyişin Post-Fordist süreçte tamamen değiştiği gözlemlenmektedir. Fordizmin işçi sınıfına sunduğu bütün bu imkanlar, devlet planlamasıyla yapılandırılmış 'sanayi/işçi' kentleri neo-liberal kentsel dönüşüm sürecinde yıkıma uğramış; yerine Post-Fordizm' in imtiyazlı sınıfları için ihtişamlı, göz alıcı, soylulaşmış 'küresel kentler', 'marka kentler' inşa edilmiştir. Bu süreç hala devam etmektedir. Özetle neo-liberalizmle birlikte "kentin sermaye birikiminin içinde gerçekleştiği mekân" olma işlevi değişmiş, bizzat kendisi ticarete konu olan 'Kent', soyut/somut, fiziki/ tarihi, kültürel, sosyo-ekonomik bütün varlığıyla, -ki buna, içinde üretilen hizmetleri de dahil etmek gerekir, alınıp satılabilen bir metaya dönüşmüştür.

\section{Fordizmin Sanayi Kentinden Neo-Liberalizmin Hizmet Kentine Geçiş: Küreselleşen Hizmetler ve Yeni Bir Kapitalizm}

Kapitalizmin ilk çıkışı 'kent'de ve ticaret kaynaklı sermaye birikimiyle olmuştur. Kapitalizmin başlangıç yıllarında öncü sınıf 'burjuva' feodalizmin malikane sisteminden kopuk, nispeten özerk yapısıyla kentlerde yaşamaktaydı. 
O dönemde 'kent' feodal örgütlenmeden uzak, kırsaldan farklı bir yaşam biçimini ve değerleri temsil etmekteydi. Bugün yeniden ticarete dayalı bir sermaye birikim sistemine dönüş olduğu görülmektedir. Ama daha komplike biçimde 'uluslararası akışkanlığı' olan 'hizmet' ve finans' ağlarıyla örülmüş küresel pazarda gerçekleşen küresel bir ticaret şeklinde gerçekleşmektedir bu. Kapitalist rekabetin sermayeyi sürekli yenilik arayışına itmesi sonucu ilerleyen teknoloji, zamanla geçmişin tek tip, basit işlevsel ürünlerle toplumsal ihtiyaçların karşılandığı yaşam biçiminin geride bırakılmasını, tercihlerin, beklentilerin çeşitlendiği, nitelik ve ayrıntının çok daha önem taşıdığı oldukça karmaşık bir toplumsal yaşama geçişi gerektirmiştir. kapitalist 'rekabet' ve 'tüketici tercihleri’nin karşılıklı etkileşimi sonucu, ürün çeşitliliği ve kalitedeki farklılaşmalar, doğal olarak aynı amaca hizmet eden ama farklı şekil, fonksiyon, görünümü olan değişik etiket ve markada ürünün piyasaya sürülmesine yol açmıştır. Ürün çeşitliliği arttıkça tüketici tercihlerini etkilemek ve müşteriyi ikna etmek 'sermaye' açısından önemli bir sorun haline gelmiştir. Tanıtım, reklam, pazarlama vb. gibi faaliyetler bu noktada önem kazanmıştır. Bu da yeni hizmet kolları ve mesleklerin ortaya çıkmasına neden olmuştur. Bu sürece ivme kazandıran en önemli faktörlerden biri de hizmetlerin ticarileşmesinin önünü açan ‘özelleştirme' süreci olmuştur. Örneğin daha önce kamusal bir faaliyet olan 'eğitim' ve 'sağl1k' hizmetlerinin özelleştirilme yoluyla ticarileşmesiyle, özel sektör için yeni yeni iş sahaları, sermaye birikimi ve zenginleşme için elverişli yeni firsatlar doğmuştur. Enerji kaynaklarının, doğal gaz, su ve elektriğin özelleştirilmesi de bu konuda kâr getiren hizmet faaliyetlerinin genişlemesini, sermaye birikimi için yeni birtakım imkanların oluşmasını sağlamıştır. Yine turizm, eğlence, ulaşım, inşaat, barınma/konut üretimi, emlak satışı, tasarım, reklam, halkla ilişkiler, lojistik ve finans sektöründeki muazzam ilerlemeler sürece ivme kazandırmıştır. Bugün çok farklı nitelik ve kalitede her türlü hizmeti sunma imkanına sahip yatırımcılar gerek ulusal gerekse uluslararası müşterilere hitap etmek ve küresel pazarda yer edinmek için kıyasıya rekabet etmektedirler. Özellikle kapitalist yaşam biçiminin ve değerlerinin tüm dünyada yaygınlaşmasıyla, -en başta batı kökenli tüketim malları, sanayi ve kültür ürünleri, filmler, sinemalar, müzik, video ve diğer medya kanalları aracılığıla pompalanan batı tipi yaşam tarzı, hobileri, alışkanlıkları; yine suni olarak yaratılan ve birtakım yerel, egzotik temalarla cazip hale getirilen geleneksel, inanç odaklı ruhsal arayışlar, paket olarak sunulan kalıplaşmış yaşam biçimleri; moda haline getirilen kıyafet ve saç tipleri 
insanları spor, dans, yoga kurslarına, sağlıklı yaşam koçlarına, diyetisyenlere bağımlı kılan, sermaye tarafından bilinçli olarak metalaştırılan bir sürü ticari faaliyet ve hizmet kolunun gelişimiyle aşırı büyüyen 'hizmet sektörü tüm dünyada 'yükselen değer' haline gelmiştir. Artık yeni bir süreç, 'yeni bir kapitalizm' söz konusudur.

\section{Sermaye Birikiminde Mekanın Özellikle de Kentlerin Öneminin Artması: Neo-Liberalizmin Misafirhaneleri 'Küresel Kentler}

Yukarıda bahsi geçen tüm o hizmetlerin ve ürünlerin ticarileşerek küreselleşmesi, küresel pazara eklemlenerek uluslararası düzeyde faaliyetlere dönüşmesi esas olarak küresel ağın ticaret merkezleri olan 'küresel kentler' bağlantısıyla gerçekleşmektedir. Diğer bir deyişle ulusal devletler bugünkü küresel pazara 'küresel kentler' aracılığı ile bağlanmakta, en gelişmiş küresel kenti olan, küresel kentini en başarılı şekilde pazarlayan ulusal devletler küresel pazarda da en büyük paya sahip olabilmektedirler. Bugün Londra, Paris, New York, Tokyo, Hong Kong, bu tür küresel kentlere örnektir. küresel kentler ayrıca Alfa, Beta, Gama gibi birtakım gruplara ayrılmaktadır. Kentlerin dünya üzerindeki konumlarını ve önemlerini derecelendiren GaWC' (Globalization and World Cities) Research Network'e göre 'dünya küresel kentler derecelendirmesi’ aşağıdaki şekilde bir sınıflandırmayla yapılmaktadır:

Genel sınıflama Alfa, Beta ve Gamma şeklinde olup; bunların da kendi içerisinde Alfa++, Alfa+, Alfa, Alfa-; Beta+, Beta, Beta-; Gamma+, Gamma, Gamma- vd.... şeklinde ayrımları bulunmaktadır. 2020 GaWC Research Network derecelendirmesine göre Türkiye'den sadece İstanbul ve Ankara, Bankok, Boston, Dublin, Lisbon Montreal, Prague, Riyadh, Vienna, Zurich gibi kentlerle birlikte ancak Alfa(-) de yer alabilmeyi başarmıştır. Yine 2020 GaWC Research Network derecelendirmesine göre Londara ve New York Alfa $(++)$, Bejing, Dubai, Hong Kong, Paris, Shanghai, Singapore, Tokyo ise Alfa $(+)$ kategorisinde yer almaktadır. $\mathrm{Bu}$ arada 'dünya küresel kentler derecelendirmesinde' belli kategorilerde yer alabilen ülkelerin aynı zamanda dünya global gelirinden en yüksek payı alabildikleri, küresel pastadan en büyük parçaya sahip olabildikleri gözlemlenmektedir. 'Küresel kentler' bir anlamda ülkelerin 'dünyaya açılan penceresi', yerel/uluslararası misafirlerini ağırladıkları 'küresel misafirhaneler’e dönüşmüştür. Bugün devletler Formula 1, Eurovision, Olimpiyatlar, uluslararası turnuvalar, fuarlar, kongreler vs. gibi uluslararası 
faaliyetlerin kendi kürese kentlerinde yapılması için kıyasıya rekabet etmektedirler. Bunun sebebi bu yolla ülkelerine kazandıracakları prestij ve saygıdan çok, o küresel faaliyetlerin ülke ekonomilerine sağlayacağı katkı ve gelirdir. Örneğin Türkiye'nin de İstanbul'la katıldığı 2020 Olimpiyatlarının hangi ülkede yapılacağına dair yarışta dünyanın çok önemli 'marka kentleri'/ küresel kentleri birbirleriyle yarışa girmişlerdir. Yarışmayı 'Tokyo' kazanmıştır. Böylece olimpiyatlar kanalıyla Tokyo’ya gelen tüm ziyaretçilerin daha uçakla Tokyo'ya ulaşımından başlayarak, konaklama, yeme, içme, eğlenme vs. için aldıkları bütün hizmetin karşılığı olan para (döviz)'in 2020 olimpiyatları kanalıyla Japonya'ya gitmesi kararlaştırılmıştır. Bu arada 2020 Mart ayında tüm dünyayı etkisi altına alan 'korona pandemisi' dolayısıyla Tokyo Olimpiyatının ertelenmesi söz konusudur. Yukarıdaki örnekte görüldüğü üzere günümüz neo-liberal sisteminde çok 'kent'e özel bir anlam yüklenmektedir. Kent artık kapitalizmin kendini yeniden üretirken ihtiyaçlarına göre şekillendirdiği 'fiziki' bir mekan değildir. Edward Soja' nın da vurguladığı gibi 'kent' günümüz esnek ekonomisinin asıl dinamiğini oluşturan temel bir olgudur. Bu bağlamda 'kent' tarihte daha önce hiç olmadığı kadar önem kazanmakta, sadece ekonomiyi şekillendirmekle kalmayıp aynı zamanda ekonomide ne oluyorsa her şey kentin içinde olmaktadır. Ekonomik gelişme bizzat kentin içinde gerçekleşmekte, davranışlarımız, ekonomik ve ticari faaliyetlerimiz, kültür ve sanat olayları, politika her şey kentte biçimlenmektedir (Soja, 2005: 66, 67). 'Küresel kent' (global city) kavramını ilk kullanan kuramcılardan ünlü sosyolog Saskia Sassen, 'küresel kent' kavramını, küreselleşmeyle ortaya çıkan 'yeni kent olgusunu' diğer dünya kentlerinden ayırmak amacıyla kullandığını belirtmektedir. 1991' de yayımladığı 'The Global City: New York, Londra, Tokyo' adlı kitabında Sassen, küreselleşmeyle birlikte 1980"lerle gelişen ve yeni bir sürece giren dünya ekonomisinin büyük kentler ile olan etkileşimini ve söz konusu kentlerde ortaya çıkan değişimi gözlemleyerek 'yeni bir kent' tipinin oluştuğunu savunmuştu. "Sassen'e göre finansal ekonominin genişlemesi ve uluslararası olması, nispeten küçük olan finansal pazarların da büyümesini ve küresel ekonominin genişlemesini destekleyen bir büyümeyi getiriyordu. Ancak endüstrinin en üst düzeyindeki kontrol ve yönetimi Londra, New York ve Tokyo gibi çok az sayıdaki finansal merkezde toplanıyordu” (Aktaran: Yazman, 2010). Hall'a göre 'dünya kenti' ya da 'küresel kent' finans ve yönetimi de içine alan, gerek önemli ekonomik faaliyetlerin gerekse büyük eğitim ve kültür aktivitelerinin yer aldığı, tıp ve hukuki konular başta olmak üzere değişik 
alanlarda uzmanlaşmış insanların yoğunlaştı̆̆ yerleşim yeridir (Hall, 1984). Gottman ise 'küresel kent' kavramını ilk olarak 1989'da yayınlanan 'Global Bir Toplumda Kentler' (Cities in a Global Society) başlıklı derlemede yer alan makalesinde dile getirmiştir. Gottman bu kavramın kendisinden de önce 1915'te de İskoç plancı Giddens tarafından dönemin yeni büyük metropoliten alanlarını tanımlamak için kullanıldığını belirtmektedir. Hall 1966'da yazdığı 'Dünya Kentleri' (Wold Cities) başlıklı kitabında dünya kentlerini dünyanın en önemli belli başlı aktivitelerinin yoğunlaştığı şehirler olarak tanımlamaktadır. Dünya kentleri sanayi kenti özelliklerini hala taşıyan, güçlü ulusal hükumetlerin, yanı sıra bazen uluslararası otoritelerin de yer aldığı kentlerdir. Bu konuda Friedmann küresel kentin özellikle küresel ekonominin kontrol, yönetim ve organizasyon merkezi olma özelliğini öne çıkarırken (Friedman, 1995) Sessen ise küresel kentlerin sadece kontrol ve yönetim merkezi olmadıklarını, aynı zamanda ticaret ve hizmet sektörü ile finansal yeniliklerin üretiminin de gerçekleştiği yaratıcı merkezler olduğunu belirtmektedir (Sassen, 1991). Yine Giddens'in de içinde bulunduğu bazı kuramcılar bugünkü küreselleşmeyi daha önceki küreselleşme olgusundan ayırmakta ve buna ait en önemli özellikler olarak bugün ticareti yapılan mal ve hizmetlerin çeşitliliğinin artmasını ve finansal piyasaların eskisine göre çok daha genişlemiş olmasını göstermektedirler. Burada küreselleşmeyi işaret eden en önemli ip ucunun ise, ticaretin küresel ölçekte yaygınlaşmasının olduğunu söylemektedirler (Giddens, 1999). Bunlara göre, eskiden ticarete konu olan ham madde, tarımsal ürün ve madencilik ürünleri yerine artık finans ve uzmanlaşmış hizmetler gerektiren ürünler ekonomik işlemlerin ana kalemleri haline gelmişlerdir (Sassen, 1994). Friedman bu görüşlere yeni bir katkıda daha bulunarak, küresel kentlerde asıl belirleyici unsurun, hizmet sektöründeki büyümenin olmadığını, çünkü bu türde bir büyümenin diğer kentlerde de mevcut olduğunu; burada önemli ve diğer kentlerden farklı olanın küresel kentte bu servisleri ve bütün ekonomik faaliyetleri 'ulusal' ya da 'iç' dinamiklerin değil, 'küresel' ekonomik işleyiş̧in belirlemesinin olduğuna dikkat çekmiştir (Friedmann, 1986).

\section{Fordizmin 'İşçi Kenti’ ile Neo-Liberalizmin 'Küresel Kent'inin Karşılaştırması}

Fordizm öncesi yaygın birikim rejiminin 'mutlak artı-değer' krizine (aşırı emek sömürüsüne) yanıt olarak sermaye ve emek arasında tarihi bir uzlaşma gerçekleşmiş; bizzat ulusal devletlere bu konuda sorumluluk yüklenerek, sınıflar 
arası gelir adaletsizliğinin ortadan kaldırması ve her bireyin mümkün olduğunca milli gelirden yüksek pay almasını hedefleyen düzenlemeler yapılmıştır. Bu arada Fordizm'de üretim ve sermaye birikimi kentlerde ve büyük fabrika sistemi içinde gerçekleştiği için, üretimin zaruri bir ayağı olan işçiler (üretici sınıf) kentin önemli bir bileşeni haline gelmiş, kent işçilerin ihtiyaç ve beklentileri gözetilerek yeniden planlanarak düzenlenmiştir. Fordizmin kenti ağırlıklı olarak işçi kenti niteliğindedir. Kentin nüfusunun sınıflara göre dağılımı, kent mekanlarının yoğun işçi nüfusuna göre yeniden tasarlanması bütün bunlar devlet eliyle ve planlama yoluyla gerçekleştirilmiştir. Temel ihtiyaç ve hizmetlerin devlet tarafından daha ucuza karşılanması amacıyla kent merkezinde ve kentin önemli yerlerinde kamu iktisadi teşebbüsleri, halka açık sosyalleşme alanları, çocuklar için oyun parkları vb açılmıştır. İşçilere ait lojman veya ekonomik konutlardan oluşan mütevazı semtler; işçilerin alım gücünün düşmemesi amacıyla sağlanan parasız okullar ve ucuz sağlık hizmetleri, kentin en gözde alanlarında yer alan kamu kurumları, devlet okulları, devlet hastaneleri vb. bulunmaktadır. Herkesin ülke kaynak ve olanaklarına eşit mesafede erişimini sağlayan kamusal alanlar, hizmetler Fordist kentin, dolayısıyla refah devletinin başlıca özellikleridir. Bu anlamda bugünkü küresel kapitalizmin 'soylulaşmış’ lüks içindeki imtiyazlı kentlerine kıyasla Fordizm’in işçi kentleri daha mütevazi, planlı, kamusal yararın ön planda tutulduğu, kent olanak ve hizmetlerine erişimde firsat eşitliği açısından daha demokratik kentlerdir.

Dünya' da özellikle 1980'lerde yaygınlık kazanan, neo-liberal kent politikaları çerçevesinde inşa edilmeye başlayan bugünün neo-liberal 'soylulaşmış' kentlerinde ise durum bunun tersidir. Fordizm' in mütevazı, işçi kentlerinin aksine neo-liberalizmin aristokrat küresel kentlerinin sakinleri kapitalizmin beyin takımıdır; üst düzey yöneticiler, tasarımcılar, modacılar, finansçılar, müteahhitler, mimarlar, mühendisler, yani yaratıcı sınıftır. Eski kent yıkılarak ve sakinleri bu yaşam alanlarından kentin çeperlerine gönderilerek, 'kent' kapitalizmin üst gelir grupları için yeniden inşa edilmiştir. Bunların talep ettiği her türlü lükse, konfora, imtiyaza sahiptir; her türlü ihtiyacın en kaliteli ve en üst düzeyde karşılanabildiği kaynak ve olanaklara sahiptir. Küresel kent esas olarak müşteri odaklıdır ve kendisi de ticari bir nesne olup değişim değerine sahiptir. Diğer bir deyişle küresel kent rekabet gücü yüksek, soyut-somut bütün varlıklarıyla metalaşmış, pazarlanabilir bir kenttir. Yüksek standartta ulaşım yolları, havaalanları, otobanları, otelleri, restoranları, eğlence ve rekreasyon merkezleri, lüks ve ihtişamlı güvenlikli siteleri, dev AVM'leri, görkemli iş ve 
kongre merkezleri bulunmaktadır. Fordizm'in mütevazi kentine ait kamusal alanların, yeşil alanların, orta sınıfa hitap eden ucuz kamu binaları ve konut alanlarının, devlet okulu ve devlet hastanelerinin yerini bu göz alıcı, tasarımı ve mimarisiyle dikkat çeken gösterişli post modern binalar almıştır. Fordizm'in halka acık kamusal alanları daralmış; özel sektöre ait işletme ve kurumlar, lüks oteller, özel okullar, özel hastaneler, çeşitli özel mülkiyet alanlarına dönüşmüştür. 'Küresel Kent' ayrıcalıklıların kentidir ve pahalıdır; kente erişimin, hizmet ve olanaklardan faydalanmanın bedeli yüksektir. Fordizmin işçi kentinin aksine kent hizmet ve olanakları, kente ait alanlar herkese açık değildir ve erişimde adalet ve firsat eşitliği yoktur; herkes maddi imkanları ölçüsünde bunlardan faydalanabilmektedir. Kentte sınıfsal ve mekansal ayrışma belirgin şekilde bir toplumsal eşitsizliğe işaret etmektedir. Toplumsal iş bölümü ve örgütlenme de aynı şekilde eşitsiz bir şekilde gerçekleşmektedir. Toplumun üst gelir grubu kentin bütün imkan ve olanaklarını kullanarak en pahalı semtlerde refah içinde yaşamlarını sürdürürlerken, alt gelir grupları ise yüksek kiralardan dolayı bu bölgeleri terk etmek zorunda kalmış, ancak oradaki varlıklı ailelerin evlerini temizlemek, işlerini görmek, çocuklarına bakmak amacıyla bu pahalı yerlere gelebilmektedirler. Burada astronomik fiyatlarla sunulan hizmetlerden ve ancak parası olanların faydalanabildiği imkanlardan ise yoksun durumdadırlar. Diğer bir deyişle neo-liberalizmin 'soylulaştırılmış' kentleri, kent olanaklarına ve hizmetlerine erişim konusunda Fordizmin işçi kentlerine göre daha antidemokratik ve imtiyazlilar kentidir.

Önemli bir diğer farklılık da Fordizmin ve neo-liberalizmin kendini yeniden üretme mekanlarıyla ilgilidir. Fordizmde 'Sermaye' kendini yeniden üretmekte olduğu ulusal sınırlar içinde hareket alanını kısıtlamış, 'kendisini yeniden üretmenin mekanı' olarak 'ulusal pazar'ını belirlemiştir. Neo-liberalizmin kendini üretme mekanı ise tüm dünya yani 'küresel pazar'dır. Bu açıdan iki farklı kapitalist döneme ait kent yapılanmasının, hakim kapitalist üretim ilişkileri ve birikim rejiminin gereklerine göre şekillenmiş birbirlerinden farklı işlev ve özellikleri vardır. Neo-liberal dönemin aksine Fordizmin kentlerinde kamu yararı her şeyin üstündedir. Emekçi kesimin talepleri gözetilerek planlanan Fordizmin sanayi/işçi kentleri yukarıda da vurgulandığı üzere daha demokratik özelliklere sahiptir. Bunun sebebi: işçilerin birbirleriyle etkileşebileceği, sosyalleşebileceği, erişimi herkese açık kamusal alanların yaygınlaştırılmasına önem verilmiştir; okul, hastane gibi kamu hizmeti veren kurumların kentin merkezi ve ulaşımı kolay yerlerinde inşa edilmesine özen gösterilmiştir; hatta 
kent kaynakları ve olanaklarının toplumsal sınıflar arasında eşit ve adaletli paylaşımının sağlanması için 'kamusal yarar' her şeyin üstünde tutulmuş, adeta kutsallaştırılmıştır. Kamu Yararının söz konusu olduğu durumlarda bireysel hak ve özgürlükler ikinci plana atılmıştı’'(Şahin, 2015: 62). Sonuç olarak Fordizmde kentler esasen işçi sınıfının ihtiyaç ve beklentilerini karşılayacak, hayatını kolaylaştıracak şekilde düzenlenmiş ve planlanmıştır. 'küresel kent' ise tamamen 'elitlerin kenti' olarak tasarlanmıştır. Hizmet sektöründe çalışan üst düzey meslek grubu ve yöneticilerden, küresel sermaye patronlarından, yaratıcı özelliği olan tasarımcılardan ve sanatçılardan oluşan küresel kentin sakinleri kent merkezinde emekçi kesimle çok yakın mekanlarda, ortak bir yaşamı paylaşarak yaşamayı tercih etmemektedirler. Onlar için 'eski kent' yıkılarak daha konforlu, ihtişam içinde olanaklarla 'soylulaştırılmış’ küresel kentler inşa edilmek istenmektedir. Bu arada 'eski kentin yıkılıp yeniden inşa edilmesi sürecinde özellikle inşaat sermayesi için birçok zenginleşme firsatı ve 'sermaye birikim olanağı ortaya çıkmıştır.

\section{Post-Fordist Sermaye Birikim Sürecinin Temel Dinamikleri: Hizmet ve Finans Kapitalin Yükselişi, Özelleştirmeler, 'Küresel Kent' ve' Marka Kent'ler inşa eden İnşaat Sektörü ve Neo Liberal Kentsel Dönüşüm Projeleri}

Yerli-yabancı çok sayıda ziyaretçisi bulunan ve bunlardan gelir sağlanan küresel kentlerde, ihtiyaçların en üst düzeyde ve en yüksek standartlarda karşılanması çok önemlidir. Mekanlar, yeme, içme, konaklama, ulaşım, eğlence ve sosyalleşme alanları, kentte üretilen hizmet ve faaliyetler, tarihi, kültürel etkinlikler bütün her şey kent sakinlerinden ziyade 'ziyaretçiler' ve /veya 'konuklar' içindir. Çünkü onlar kentin gelir getiren müşterileridir aynı zamanda. Gelir akışının sürekliliği için müşteri memnuniyeti her şeyin üstündedir. Konuklarını en iyi ağırlayan, en kaliteli en konforlu hizmeti sunan, alt yapı imkanları en gelişmiş, zengin tarihi ve kültürel mirası olan, ziyaretçilere en fazla seçenek ve çeşitlilik sunan, yaratıcı etkinlik ve faaliyetler üretebilen markalaşmış, vizyon sahibi ‘küresel kentleri’ bulunan ülkelerin dünya küresel gelirinden de en yüksek payı aldıkları görülmektedir. Bu süreçte sermaye birikiminin önemli bir bölümü 'küresel kentler' aracılığı ile bu şekilde küresel ölçekte üretilen ulusal ve uluslararası mal ve hizmetler üzerinden sağlanmaktadır. 
Sermaye birikiminin diğer bir kaynağını ise ‘özelleştirmeler’ oluşturmaktadır. Bu sayede, daha önce halka açık olan kamusal alanlar, birtakım stratejik önemi olan devlet arazileri, devlet okulları, devlet hastaneleri, üniversiteler, parklar, plajlar, sahiller, yaylalar, ormanlar vb. gibi kamu arazileri/kurumları, lüks otel , AVM ya da diğer tür ticari amaçlı tesis/bina, konut yapılmak üzere belli bir 'birey' ya da 'sermaye grubunun' tasarrufuna birakılmak suretiyle özelleştirilmekte, böylece kamu kesiminden sermayeye önemli bir gelir transferi gerçekleştirilmektedir. Buna ek olarak daha önce kamu tarafindan halka parasız ya da ucuza sunulan bazı hizmetlerin özel sektöre devredilerek ve birtakım kar getirici ticari faaliyetlere dönüştürülmesi suretiyle de yine 'sermaye sınıfı' lehine bir gelir aktarımı yapılmakta ve sermaye birikimine katkı sağlanmaktadır. $\mathrm{Bu}$ süreçte kapitalist devlet de halkın/kamunun hakkı olan ülke kaynak ve olanaklarının sermaye lehine yeniden dağılımını sağlayacak düzenlemeleri yaparak ve gerekli yasal alt yapıyı hazırlayarak, neo-liberal sermaye birikim sürecinin güvenceye alınmasındaki kendi rolünü yerine getirmektedir.

Neo-liberal süreçte bir diğer 'sermaye birikimi' sağlayan kaynak da 'kentsel dönüşüm' projelerinden sağlanan gelirlerdir. Diğer bir deyişle 'inşaat odaklı kentsel dönüşüm modeli’ ile elde edilen sermaye birikimidir. Bu sürecin özellikle Türkiye'de şu şekilde gerçekleştiği gözlemlenmektedir. Öncelikle yüksek arsa rantı nedeniyle, tarihi ve turistik alanlar, devlet okulları, devlet hastaneleri, parklar, ormanlar, tarım ve su havzaları, yeri değerlenmiş halka ait konut alanları, sanayinin getirdiği kirlilik yüzünden tercih edilmeyen ama dönüştürüldüğünde getirisi yüksek olabilecek gecekondu bölgeleri, kent dışında, kırsalda yaylalar, ormanlar, plajlar, arsa değeri yüksek tüm bu alanlar 'yenileme alanı' ilan edilerek 'kentsel dönüşüme' tabi tutulmakta; ihtiyaca yönelik değil 'mübadele odaklı' bir konut ve yapı üretimi gerçekleştirilerek ve bunlar sonradan astronomik fiyatlarla satılarak ülke ortalamasının üstünde bir gelir ve sermaye birikimi' sağlanmaktadır. Süreçle ilgili ilk adım evlerin ve/veya kentsel dönüşüme girecek bölgenin boşaltılmasıdır. Bu orman arazisi ise ağaçların kesilmesidir; konut alanı ise evlerin boşaltılmasıdır. Evler, 'acele kamulaştırma' ile inşaat firmalarına sağlanan avantaj sayesinde en ucuz maliyetle, adeta el konularak sahiplerinin elinden alınmakta; süreç içinde altgelir grubuna ait bu yoksul bölgeler yerel halktan arındırılarak 'soylulaştırılmak' üzere inşaat firmalarına teslim edilmektedir. Bu konuda devletin yaptırım gücü ve neo-liberal politikalar kapsamında çıkarılan imar/inşaat yasa ve düzenlemeleri sayesinde ortaya çıkabilecek pürüz ve engeller zaman içinde giderilmekte, 
inşaat firmalarının işlerinin kolaylaştıracak önlemler adım adım gerçekleştirilmektedir. Çalışmanın başlarında da belirtilen 5366, 6306 nolu 'afet yasası' gibi yasalar bu kapsamda çıkarılan yasalardır. Bu yasaların hepsine, sermaye için en zor iş olan inşaat alanlarının yerel halktan arındırılarak 'arsalaştırılması' sürecine hizmet etmek üzere, evlere, mülklere müteahhit lehine el koymanın önünü açan 'acele kamulaştırma' maddesi eklenmiştir. 'Acele kamulaştırma' aslında mülkiyet hakkını ihlal eden, tapu tasarruf hakkını mülk sahibi aleyhine kısıtlayan bir düzenlemedir. Asli görevi mevcut sermaye birikiminin sorunsuz, kesintisiz sürmesini sağlamak olan neo-liberal politikaların bu süreçteki misyonu da, esas olarak, dönemin hakim sınıfı olan inşaat sermayesinin imar ve inşaata yönelik ihtiyacı olan düzenlemelerin yapıldığı, gerekli yasal altyapının hazırlandığı bu aşamada gerçekleşmektedir. Bu yasal düzenlemelerle sürecin önemli bir parçası olan 'kentsel dönüşüm' projelerinin uygulanmasının önündeki engeller de kaldırılmış olmaktadır. Türkiye'de doğayı, çevreyi, yaşamın sürdürülebilirliğini tehdit etmek pahasına sermaye lehine çıkarılan yasaların sayısı son dönemde o kadar artmıştır ki, 'kamu yararı' bir yana bırakılarak doğrudan sermayenin çıkarları için gerçekleştirilmiş bu taraflı 'hukuk düzeni' ve 'adalet sistemi' bugün artık 'kamu vicdanını' rahatsız edecek düzeye ulaşmıştır. Örneğin kısa bir zaman önce Şehip Plancıları Odası (ŞPO) nın 'doğanın tahribatına yönelik' açıkladığı birtakım imar ve inşaata yönelik 'korumacılığa aykırı düzenlemeler, Türkiye'de doğaya ve çevreye duyarlı biçok insanın endişelerini de arttırmıştır. 5 Nisan 2020 tarihinde Ekoloji Birliği internet sitesinde de yayınlanan (hala yayında olan) SPO'nun raporuna göre "sit alanlarının koruma statülerinin parça parça değiştirildiği, sit alanlarının daraltıldığ1 ve koruma statülerinin düşürülmesi sonrasında, yapılan bu değişiklikle bir de kullanma koşullarındaki kapsamın genişletildiği; $\mathrm{Bu}$ yönetmelik değişikliği ile İzmir'de de korunması gerekli birçok doğal alanın tehdit altına girdiği; Foça, Urla ilçeleri ile Karaburun, Çeşme Yarımadaları ve ülkemizin en önemli sulak alanlarından biri olan Gediz Deltası başta olmak üzere korunması gerekli doğal sit statüsündeki alanların, doğal niteliklerinin bozulmasının önünün açıldığı ve söz konusu nitelikli alanların yapılaşma tehdidine açık hale getirildiği” ifade edilmektedir. Raporda ayrıca Ayrıca son dönemde kamuoyu gündeminde olan “Çeşme Kültür ve Turizm Koruma ve Gelişim Bölgesi” ilanı ve bu bölge için alınmış 'acele kamulaştırma' kararlarının da bu sürecin parçası olduğu hatırlatılmaktadır. Bu konuda 'Egeli Gazete' sinde yer alan açıklamada da bu yönetmelik değişikliği ile Nitelikli Doğal Koruma 
Alanlarında, entegre nitelikte olmayan tarım ve hayvancılık tesisleri ile balıkçı barınăğ, iskele, kültür balıkçılığı ve doğal kaynak suyu kullanımına yönelik uygulama ve yapılaşmalara izin verildiği vurgulanmakta, Sürdürülebilir Koruma ve Kontrollü Kullanım Alanları' nda da, diğer koruma statülerinde yapılabilecek yapı ve faaliyetlerin yanı sıra sanayi tesislerini de içerecek biçimde entegre üretim ve depolama tesisleri ile madencilik faaliyetlerinin yapılmasına olanak sağlandığına dikkat çekilmektedir.

Devletten ve yasalardan güç alınarak 'acele kamulaştırma' yoluyla el konulmuş, boşaltılmış, arsaya dönüştürülmüş yerleşim alanlarında, orman arazilerinde, tarım ve su havzaları ve hatta 'sit alanlarında'; genel olarak da 'korunması gerekli' ama sonradan üzerindeki korumanın kaldırıldığı 'dönüşüm' alanlarında bu şekilde üst gelir grubuna hitaben lüks konutlar, oteller, AVM'ler, ihtişamlı, görkemli lüks binalar inşa edilerek ve bunlardan maliyetinin çok üstünde astronomik kazançlar sağlanarak ülkede belli bir azınlığın imtiyazlı gelir elde etmesinin yolu açılmaktadır. İnşaata dayalı bu büyüme modelinde sadece kentler hedef alınmamaktadır; yukarıda da vurgulandığı üzere hizmet sektörünün işine yarayacak her türlü arazi, bina, okul, hastane, park, koru, yayla, bostan, tarihi sit alanları, tarım alanları, su havzaları vb. bu sürecin bir parçası haline getirilip dönüştürülmektedir. Türkiye'de günümüzde bu politikalar yüzünden doğa talanın, ağaç katliamının ve betonlaşmanın son derece arttığ görülmektedir. Ayrıca bir de büyük ölçekli inşaat projeleri vardır. Örneğin, baraj, maden, enerji santralleri, köprüler, metro ve yol inşaatları vs... Tüm bu projeler ve neo-liberal kentsel dönüşümün sürecinin sağladığg avantajlarla bugün Türkiye'de inşaat sermayesinin ciddi bir servet birikimine ulaştığ gözlemlenmektedir... Bu anlamda yukarıda bahsedilen üç 'sermaye birikim' yönteminden en önemlisi olmasa da 'en stratejik' olanı, kendisine bağlı bir sürü iş kolunun olması ve bunların kazanç sağlamalarının da dolaylı yoldan kendisine bağlı olması nedeniyle, inşaat sektörüdür. 'İnşaata dayalı sermaye birikim modeli' bu yönüyle neo-liberal sürecin motor gücünü oluşturmaktadır. Çünkü hizmet sektöründeki bir çok iş sahası, ancak inşaat sektörü ayakta kalırsa faaliyetini sürdürüp kazanç sağlayabilmektedir. Örneğin peyzaj ve mimarlık hizmetleri, emlakçılık ve reklamcılık; inşaat sektörüne mal temin eden demir, çelik, kum, cam, çimento, boya, ahşap, parke vs. satışına dayalı iş kolları,; binaların içindeki bütün dekor tasarım işleri; inşatlar bittikten sonra evlerin döşenmesi için alınan eşyalar, başta beyaz eşya olmak üzere bütün eşyaların satışı; inşaat sektörünün iş yapmasından doğrudan ya da dolaylı olarak etkilenen 
ticari faaliyetlerdir. Özellikle Türkiye gibi sanayileşme düzeyi düşük, üretim ekonomisi zayıf, tüketim ekonomisine ve ticarete dayalı ülkelerde durum ağırlıklı olarak böyledir.

Son olarak 'Finans' sektörünün bu süreçteki rolünü açıklamak gerekirse; finans sektörünün neo-liberal süreçte, sistemin hem yatırım/üretim hem de tüketim/talep ayağı ile kesintisiz sürmesini sağlayacak 'nakit döngüsünü güvence altına almak' bakımından 'hayati’ bir önemi bulunmaktadır. Bankalar hem yatırımcılara hem tüketicilere aynı anda kredi sağlayarak sistemin nakit akışında sıkıntıya girmesinin önüne geçmektedirler. Örneğin 'talep' yetersiz kaldığında tüketici kredilerine ağırlık vererek bu konudaki eksikliği gidermeye çalışmakta; 'sermaye' ve 'yatırımlar' yetersiz kaldığında ise yatırımcıları destekleyecek düşük faizli avantajlı yatırım imkanları sunarak sistemin 'arz' ve 'talep' dengesini sürekli koruyacak tedbirleri almaktadırlar. Sonuçta Fordizmde bankalar daha çok 'yatırım' ağırlıklı krediler verirken ve istihdam yaratıcı politikalarla geliri arttırma yoluyla talep kontrol edilirken, -çünkü soyal devletin görevidir bunlar: talebi desteklemek, iş yaratmak, gelir yaratmak-; neo-liberal süreçte ise bankalar her iki rolü de birlikte üstlenerek, hem yatırımların kesintisiz sürmesini sağlamak için 'yatırım kredileri' vermekte; hem üretilen mal ve hizmetlerin tüketimini güvence altına alacak şekilde halka 'tüketici kredileri' sağlamaktadırlar. Bunun yanı sıra finans sektörü aynı zamanda spekülatif kazançların, parayla para kazanmanın da bir aracı haline gelmiştir. Bu açıdan finans sektörü inşaat ve turizm sektörü yanında neo-liberal sürecin en önemli kilit sektöründen birini oluşturmaktadır. Hatta sistemin nakit akışını sağlayarak adeta sistemin can damarlarını oluşturmaktadır.

\section{Sonuç}

Robert Park'1n “insanlar kentlerini üretirken kendilerini de yeniden üretmektedirler” görüşüne kısmen katılmak mümkün olsa da, bu çalışmada savunulan görüş, kenti ‘tasarlama' ve ‘oluşturma' sürecinde bireylerin tamamen özgür olmadıkları, sermayenin kendini yeniden üretme koşullarının uzam, bölge ve mekânı belirlediği gibi kenti de belirlediği ve sonuçta kapitalist üretim ilişkilerinden bağımsız bir kent oluşum ve yapılanmasının mümkün olmadığıdır. Kapitalist sistemde diğer bütün üst-yapı kurumları ve oluşumlarının olduğu gibi kentin oluşum ve dönüşüm süreçlerinde de aynı kapitalist dinamikler ve sermaye birikim yasaları geçerlidir. Çalışma boyunca sıkça vurguladığı üzere sermayenin 
kendini yeniden üretebilmesi için elverişli coğrafi, fiziki koşullara, mekânlara ihtiyacı bulunmaktadır. Bu bölge olabilir, kent olabilir; önemli olan sermayenin kendini yeniden üretme sürecinde ihtiyaç duyduğu her nesneyi, doğal yaşamı, çevreyi, coğrafyayı, mekânı kendi ihtiyaçları doğrultusunda değiştirme, dönüştürme gücüne sahip olduğu gibi, 'kır' ve/veya 'kent'i de aynı şekilde değiştirip, dönüştürüp yeniden yapılandırma gücüne sahip olmasıdır. Kapitalizmin bu belirleyici özelliği göz önünde bulundurulduğunda, dönemsel olarak her kapitalist safhada hangi nüfusun kentin hangi bölgesinde yoğunlaşacağı, kentsel alanların farklı sınıflar arasında nasıl paylaşılacağı ve bunun sonucunda ne tür 'sınıfsal' ve 'mekânsal' ayrışmalar yaşanacağı konuları, kapitalist üretim ilişkileri ve egemen güç ilişkilerinden bağımsız düşünülmemelidir.

Günümüz küresel sisteminde 'kent'e çok özel bir rol biçilmiştir. 'Kent' artık sadece kapitalizmin kendini yeniden üretirken ihtiyaçlarına göre dönüştürdüğü, biçimlendirdiği fiziki bir yapı olarak değil, bizzat küresel birikimin içinde gerçekleştiği, bütün dünya ekonomilerinin küresel kapitalizme onun aracılı̆̆ 1 ile eklemlendiği ve kendisinin de alınır satılır meta haline geldiği, ticarileştiği oldukça karmaşık, dinamik bir olgu olarak karşımıza çıkmaktadır. Daha önceki bölümlerde Soja tarafindan vurgulandığı üzere, günümüzde bölgeler ve her bölgede yer alan 'küresel kentler' esnek ekonominin temel dinamiğini oluşturmaktadır. Bu bağlamda 'kentler' bugün tarihte daha önce hiç olmadığ1 kadar önem kazanmaktadırlar. Öyle ki sadece ekonomiyi şekillendirmekle kalmayıp aynı zamanda ekonomide ne oluyorsa kentin içinde olmakta; ekonomik gelişme bizzat kentten sağlanan kazançla, yani kentin kendisi de metalaşarak gerçekleşmektedir. Kentte üretilen her artı-değer, yani kültür, sanat, tarih, politika vb.gibi değerler arttıkça kentin değişim değeri de artmaktadır (Soja, 2005, s.66, 67).

Post Fordist neo-liberal sermaye birikim sürecinde, zenginliğin, yani sermaye birikiminin başlıca üç yolu/yöntemi bulunmaktadır. Bunlardan birincisi metalaşmış/markalaşmış kentler/şehirler, hatta kır/köy ve burada üretilen hizmetlerdir. İkincisi bu hizmetlerin içinde gerçekleştiği kentlerin, özellikle de küresel kentlerin yeniden inşası ve diğer yapılaşmaya yönelik inşaat süreçlerinin sağladığı zenginleşme ve sermaye birikimidir. Bu bağlamda inşat faaliyetlerinin kendisi yanı sıra arsa rantlarının da emek aleyhine sermaye lehine önemli bir gelir aktarım mekanizmasına dönüştüğü görülmektedir. Son olarak da kamusal alanların ve birçok kamu hizmetinin özelleștirilmesi sonucu ülke veya dünya 
kaynak ve gelirlerinin yine emek aleyhine sermaye lehine yeniden paylaştırılması ve kamudan (halktan) sermayeye doğru yeniden bir gelir aktarımının gerçekleştirilmesiyle de sermaye birikimi sağlanabilmektedir. Son y1llarda Türkiye'de bu yolla çok ciddi servet birikimi edinen sermaye gruplarının olduğu bilinmektedir.

Bu süreçte neo-liberal politikaların görevi, mevcut sermaye birikiminin önünü açmak, özellikle de ekonominin itici gücü olan inşaat sektörünün faaliyetlerini kısıtlayan yasal ve kurumsal engelleri ortadan kaldıracak düzenlemeleri yapmaktır. Günümüzde devletlerin talep arttırıcı, gelir ve istihdam yaratmaya yönelik 'sosyal devlet' misyonu -sözde hala varmış gibi ifade edilse bile- ortadan kalkmıştır. Bu konuda ihtiyaç duyulan açığı giderme görevini 'yardımlar' konusunda 'sivil toplum', nakit ihtiyacını giderme konusunda da 'finans' sektörü' üstlenmiştir. Sivil toplum oluşumları halkın ihtiyaç ve taleplerine göre yardım ve bağışlarda bulunarak yoksullaşmanın toplumda yaratabileceği sorunlara kısmi çözümler üretirken ve bu şekilde ortaya ç1kabilecek toplumsal tepkileri azaltırken, "üretim ve tüketimin döngüsünün kesintisiz sürdürülmesi” gibi kapitalizmin en temel sorununun çözümü ise 'finans' sektörü'ne bırakılmıştır. Finans sektörü bugün 'kapitalizmin krize girmemesini güvenceye almak' gibi çok önemli bir rolü üstlenmiştir. Finans sistemi hem 'yatırım' krizine hem de 'tüketim/talep' krizine yol açabilecek her türlü riske karşı gerekli önlemleri almalı, yatırımlar eksildiğinde yatırım teşvik ve kredileri ile yatırımcıları, tüketimde/talepte bir sorun olduğunda da tüketiciye sağlayacağı düşük faizli kredilerle tüketiciyi desteklemelidir. Böylece sistemin ihtiyaç duyduğu 'yatırımlar' yanı sıra üretim sürecinde üretilen her türlü mal ve hizmetin tüketimini sağlayacak nakit akışının güvencesini sağlamak da yine finans sektörüne düşmektedir. İnşaat sektörü battı̆̆ında nasıl bütün ekonominin durma riski varsa, Finans sektörü battığında da sistemin çökme riski bulunmaktadır. Yani Finans sektörü kapitalizmin can damarını, kalbini oluşturmaktadır. Kalbin durması demek üretim döngüsü ve nakit akışının durması; satışların gerçekleşmemesi; bölüşülecek gelirin ortaya çıkmaması; yarınki yatırımların yapılamaması; ertesi gün üretime devam edilememesi demektir. Yani kapitalizmin iflası demektir...

$\mathrm{Bu}$ arada makalenin dayandığı, kapitalist üretim ilişkilerinin mekânı/kenti belirleme, dönüştürme gücüne sahip olduğu 'temel tezi’ yanı sıra çalışmada ayrıca ikinci bir görüşe daha yer verilmektedir; bu da hangi kapitalist safhada hangi tür 
bir kent yapılanması ve sınıfsal ayrışmanın, mekân tasarımı ve iş gücü örgütlenmesinin oluşacağının yine o dönemin 'üretim ilişkileri' ve 'sermaye birikim' koşullarınca belirleneceği anlayışıdır. Diğer bir deyişle dönemsel olarak kentler farklı yapı ve özellikler ortaya koysa da, her kapitalist dönemde kentlerin bu değişen formlarını ve işleyişlerini belirleyenin aynı sermaye birikimine özgü değişmez yasaların olduğudur. En önemlisi kapitalizmin bir 'kâr' sistemi olmasıdır. Bu kapitalizmin değişmez yasasıdır. Sermaye birikiminin kesintisiz sürmesi için kârın kesintisiz sürmesi gerekmektedir. Sistem kâr ettiği sürece, sermaye birikimini sağlayan diğer bütün koşullar değişebilmektedir. Kâr hadleri düştügünde ya da sermaye birikimi kesintiye uğradığında ise, bu 'kriz' anlamına geleceği için, sistemi yeniden 'kâr' eder hale getirecek düzenlemelerin derhal hayata geçirilmesi gerekmektedir.

Makalenin örnek çözümleme bölümünde bu çerçevede iki farklı kapitalist dönem üzerinden, Fordist ve Post Fordist süreçte ortaya çıkan iki farklı 'kent' yapılanması ele alınmaktadır. Başlangıç olarak bu iki kent oluşum sürecinin 'kapitalist üretim ilişkileri ve sermaye birikim koşulları' ile bağlantısı irdelenmektedir. Sonra Fordist işçi/sanayi kentini dönüştüren temel yasalarla Post-Fordist neo liberal sürecin küresel/hizmet kentini dönüştüren yasaların her ikisinin de aynı kapitalist sermaye birikim yasaları olduğu; diğer bir deyişle aynı sistemin 'kâr' 1nı güvence altına alan yasalar olduğu saptaması yapılmaktadır. Diğer her şey ve koşullar bu yasalara tabii olarak değiştirilebilir, sisteminin sürdürülebilirliği için bunlara müdahale edilebilir, dönüştürülebilir. $\mathrm{Bu}$ değişen dönüşen şeylerden biri de 'kent'tir. Bu yüzden Fordizmin sanayi/ işçi kenti ve Post Fordizmin küresel/hizmet kenti aynı özelliklere sahip değildir; çünkü farklı iki kapitalist dönemin koşullarına tabii olarak oluşmuş, iki farklı kent yapılanmasıdır bunlar. Bu arada Fordizm'in sanayi ağırlıklı mütevazı 'işçi kenti'nden neo-liberalizmin hizmet ağılıklı soylulaşmış 'küresel kent'ine geçişte, araştırma açısından önemli şu çıkarımlar elde edilmektedir: Fordizmin emekçilere hitap eden ucuz mekânlar ve mütevazı yaşam standardından oluşan sanayi/işçi kentinin yerini neo-liberal dönemde soylulaşmış/elitist, mekansal ve sınıfsal ayrışmaların dikkat çektiği 'küresel kent' almıştır. Yoksullaşan alt gelir grubundaki emekçiler bu süreçte kent çeperlerine sürülmüş, pahalı mekanları ve binalarıyla astronomik fiyatlara ulaşan kent merkezlerine üst gelir gruplarının yerleşimi sağlanmıştır. Fordizmin sanayi kentinin, işçi sınıfının kendini yeniden üretiminde iş gücü maliyetini düşürerek fiyatları düşük tutmak, aynı zamanda da ücretli kesimin alım gücünü koruyarak tüketim alışkanlıklarının, 
dolaysıyla da talebin korunmasına hizmet etmek gibi bir işlevi bulunmaktadır. Bu yolla kapitalizm, 1929 eksik talep krizine, yeni bir birikim rejimi ve Fordizmin tekelci düzenlemeleriyle yanıt vermiş olmaktadır; neo-liberal süreçte mütevazi sanayi/iş̧̧i kenti yıkılarak yerine ihtişamlı, gösterişli, vizyon kentlerin, marka kentlerin, yani küresel kentlerin inşa sürecinin başlaması ise kentin ticarileşmesinin, soyut, somut bütün değerleriyle alınır satılır bir meta haline gelmesinin bir sonucudur. Kent bundan böyle maddi/manevi (somut/soyut), bütün değerleriyle bir sermaye birikim kaynağ1, zenginleşme aracına dönüşmüştür. Kentte üretilen hizmet ve faaliyetler de aynı şekilde servet edinmenin ve sermaye biriktirmenin önemli bir aracı durumundadır. Artık bütün alt-yapı olanakları ve hizmet çeşitliliği ile; yerli/yabancı müşterilerine en iyi hizmeti sunacak donanım ve kabiliyete sahip küresel kentlerin baş rolde olduğu ve küresel pastadan en yüksek payı almak için birbiriyle kıyasıya rekabet ettiği ‘yeni bir kapitalizm' söz konusudur.

Fordizmin krizinin aşılması uğruna tercih edilen bu 'Küresel hizmet kentlerinin inşa edilme sürecinin doğaya ve insanlığa maliyeti çok yüksek olmuştur. Doğaya, çevreye, topluma ödettiği bedeller ağırdır ve hala devam etmektedir. Başta betonlaşma, doğanın tahribatı olmak üzere, kentin değeri artan bölgelerinden alt gelir gruplarının yerinden edilerek 'kent çeperlerine' sürülmeleri; insanların evlerini kaybetmeleri, mahallelerin, geleneksel yaşam alanlarının yıkılması; mahalle kültürünün yok edilmesi; tarihi-kültürel-sit alanların, hafıza mekanlarının tahrip edilmesi, soylulaşma ile yoksul kesimlerin dışlanması, sınıfsal, mekansal olarak ayrıştırılması; gelir adaletsizliğinin artması, ülke kaynak ve olanaklarının eşitsiz bir şekilde kamuyararı gözetilmeden sermaye lehine yeniden dağılımının sağlanması bunlar sürecin olumsuz etkileridir.

Sonuç olarak çalışmanın başlangıcından sonuna kadar savunulan ve sadık kalınan görüş, kentin dönüşüm ve yeniden yapılanma sürecinde başka etken ve koşulların da söz konusu olmasıyla birlikte asıl belirleyici olanın kapitalist 'üretim ilişkileri' ve 'sermaye birikim' yasalarının olduğudur.

Hakem Değerlendirmesi: Dış bağımsız.

Çıkar Çatışması: Yazar çıkar çatışması bildirmemiştir.

Finansal Destek: Yazar bu çalışma için finansal destek almadığını beyan etmiştir.

Peer-review: Externally peer-reviewed.

Conflict of Interest: The author has no conflict of interest to declare.

Grant Support: The author declared that this study has received no financial support. 


\section{Kaynakça/References}

Allen, J. (1993) "Post İndustrializm and Fordizm",Modernity and its Futures, (Ed.) S. Hall, D. Held, and T.Mc Grew içinde, England: Cambridge, 170-204.

Aydınl, H. İ. (2004)Sosyo-Ekonomik Dönüşüm Sürecinde Belediyeler, Ankara: Nobel Yayınları.

Brenner and Keil(2013) "Küresel Kentlerden Kentselliğin Küreselleşmesine",(Çev.) M. Üçoğlu, Birikim Dergisi, İstanbul whttp://www.birikimdergisi.com/kisi/5979/neilbrenner.

Castells, M. (1977) The Urban Question: A Marxist Approach, Edward Arnold, London. Castells, M. (1997) Kent, Sınıf, İktidar(Çev.) Asuman Erendil, Ankara: Bilim ve Sanat Yayınevi.

Çağlar, K. (1993), Ulusal Kalkınmacılığın İflası, İstanbul: Metis Yayınları.

Çınar, T.(1998). "Dünya Kenti ve Toplumsal Kutuplaşma (İstanbul Dünya Kenti Olmalı mı?), Tartışma Metinleri, No:12, AÜSBF, Aralık 1998, 73-98.

Friedman, J. (1995). "WhereWeStand: A Decade of World CityResearch", World Cities in a World System içinde, (Der.) Paul, L. Knoxand Peter, J. Taylor, London: Cembridge University Press.

Ghai, D. (1995). "Yapısal Uyum Küresel Bütünleşme ve Sosyal Demokrasi”, Piyasa Güçleri ve Küresel Kalkınma içinde, (Ed.) Renee Prendergast, Frances Stewart, (Çev) İdil Eser İstanbul:Yapı Kredi, 39-72.

Gottman, J.(1989) “Whatare Cities Becoming the Centre of?”, Sorting out the Possibilities, Cities in a Global Society içinde, (Der.) R. G. Knigt, London: Sage Publications.

Gramsci, A. (1986). Hapishane Defterleri: Seçmeler (Çev.) Kenan Somer, İstanbul: Onur Yayınları.

Gottdiener, M. (2001). "Mekân Kuramı Üzerine Tartışma: Kentsel Praksise Doğru", (Çev) H. Çağatay Keskinok, Praksis (2), Ankara: Dipnot Yayınları, 248-269.

Güven, O. (1914). "Kapitalizm ve Kent: Bir Tarihselleştirme Denemesi”, Gelenek Dergisi:124, https://gelenek.org/sayi/124/

Helvacıŏ̆lu, B. (1994). "Evvel Mekân İçinde Kalbur Zamanlar İçinde: Tarihi Coğrafi Materyalizm", Toplum ve Bilim, No:64-65, 77-89.

Hall, P.(1984). The World Cities, London: Weidenfield \& Nicolson.

Harvey, D. (2008a). Umut Mekanları, (Çev.) Zeynep Gambeti, İstanbul:Metis Yayınları

Harvey, D. (2008b). "The Right tothe City”, New Left Review, No: 53, 23-40.

Harvey D. (2004). "The Right tothe City", Emancipatory City? Paradoxes and Possibilities içinde, (Ed.) L.Lees, London: Sage Publications, 236-239.

Harvey, D. (2003). Sosyal Adalet ve Şehir, (Çev.) M. Moralı, İstanbul: Metis Yayınları.

Harvey, D. (1997). Post Modernliğin Durumu, İstanbul: Metis Yayınları.

INTES (2014) Mart 2014 İnşaat Sektörü Raporu, Türkiye İnşaat Sanayicileri İşveren Sendikasi. 
Katznelson, I. (2019). Marksizm ve Kent, (Çev.) Ceren Göğüş, İstanbul: Ayrıntı Yayınları Keyder, Ç. (1993). Ulusal Kalkınmacılığın İflası, İstanbul: Metis Yayınları.

Lefebvre, H. (2016). Şehir Hakkı, (Çev.) Işık Ergüden, Sel Yayınları.

Lefebvre, H.(2015). Kentsel Devrim, (Çev.)Selim Sezer, Sel Yayınları.

Mumford, L. (2013). Tarih Boyunca Kent, (Çev.) Gürol Koca, Tamer Tosun, İstanbul: Ayrıntı Yayınları

Marx ve Engels, (2011). Komünist Manifesto, (Çev.) Erkin Özalp, İstanbul: Yazılama Yayinlar

Park, R.(1967). On Social Control and Collective Behavior,Chicago: University of Chicago Press.

Özdemir, E. (2019) “Kentin Tanımlanmasında Sosyolojik Yaklaşımlar: Toplumsal Süreç ve/ veya Mekânın Çözümlenmesi “, İdeal Kent, Sayı 1, 44-77 ,www.idealkentdergisi.com

Saklı, A. R. (2007). Kapitalist Gelişim Sürecinde Fordizm ve Post-Fordizm, Ankara.

Sassen, S. (1991). The Global City: New York, London, Tokyo, Princetion University Press

Simonsen, K. (2005). "Bodies, Sensations, Space and Time: The Contribution From Henri Lefebvre”, Geografiska Annaler. Series B. Human Geography, No: 87(1), 1-14.

Soja, E. (2005). “Global City-Regions: İmplicationsfor Planning Theory and Practice”, 8 Kasım Dünya Şehircilik Günü 28. Kolokyum, Prof.Dr.İlhan Tekeli Oturumu, Değişen Dönüşen Kent ve Bölge içinde , Cilt I, Ankara: OTDÜ Mimarlık Fak. Ve TMMOB Şehir Planlamacıları Odası Ortak Yayını

Sönmez, F. (2012). Kapitalist Devlet ve Kentsel Mekanın Dönüşümü, Yüksek Lisans Tezi, Adnan Menderes Üniversitesi, Aydın.

Şahin, Ç. (2015). “ Türkiye’de Kentsel Dönüşüme Dayalı İnşaat Odaklı Ekonomi Modeli Ve Toplumsal Maliyeti: En Temel İnsan Haklar, Sosyal Haklar, Çevre Hakkı ve Kent Hakkı Açısından Eleştirel Bir Değerlendirme”, Sosyoloji Konferansları, No:51, 51-81.

Tallon, R. A. (2010). “İngiltere’de Kentsel Rönesans: Kentlerdeki Yansımaları ve Eleştirel Değerlendirmeler”,Kentsel Dönüşümde Politika Mevzuat Uygulama içinde, (Der.) Dilek Özdemir, İstanbul: Nobel Yayınları, 79-98.

Trut, H. ve Özgür E. M. (2018). "Klasik Kent Kuramlarından Eleştirel Kent Kuramlarına Geçiş Bağlamında Kentleri Yeniden Okumak”, Ege Coğrafya Dergisi (27) 1, İZMIR, 1-19.

Yazman, D. (2010). “Kürsel Kentler”, Arkitera, 6 Nisan 2010, https://v3.arkitera.com/ h52012-kuresel-kentler.html

Y1lmaz, O. K. (2019). "Küresel Kentler ve Türkiye Kentlerinin Küresel Kentler Arasındaki Konumları”, SUTAD, Aralık, No:47, 465-483. 
